\title{
Preparation and properties of B4C-TiB2 ceramics prepared by spark plasma sintering
}

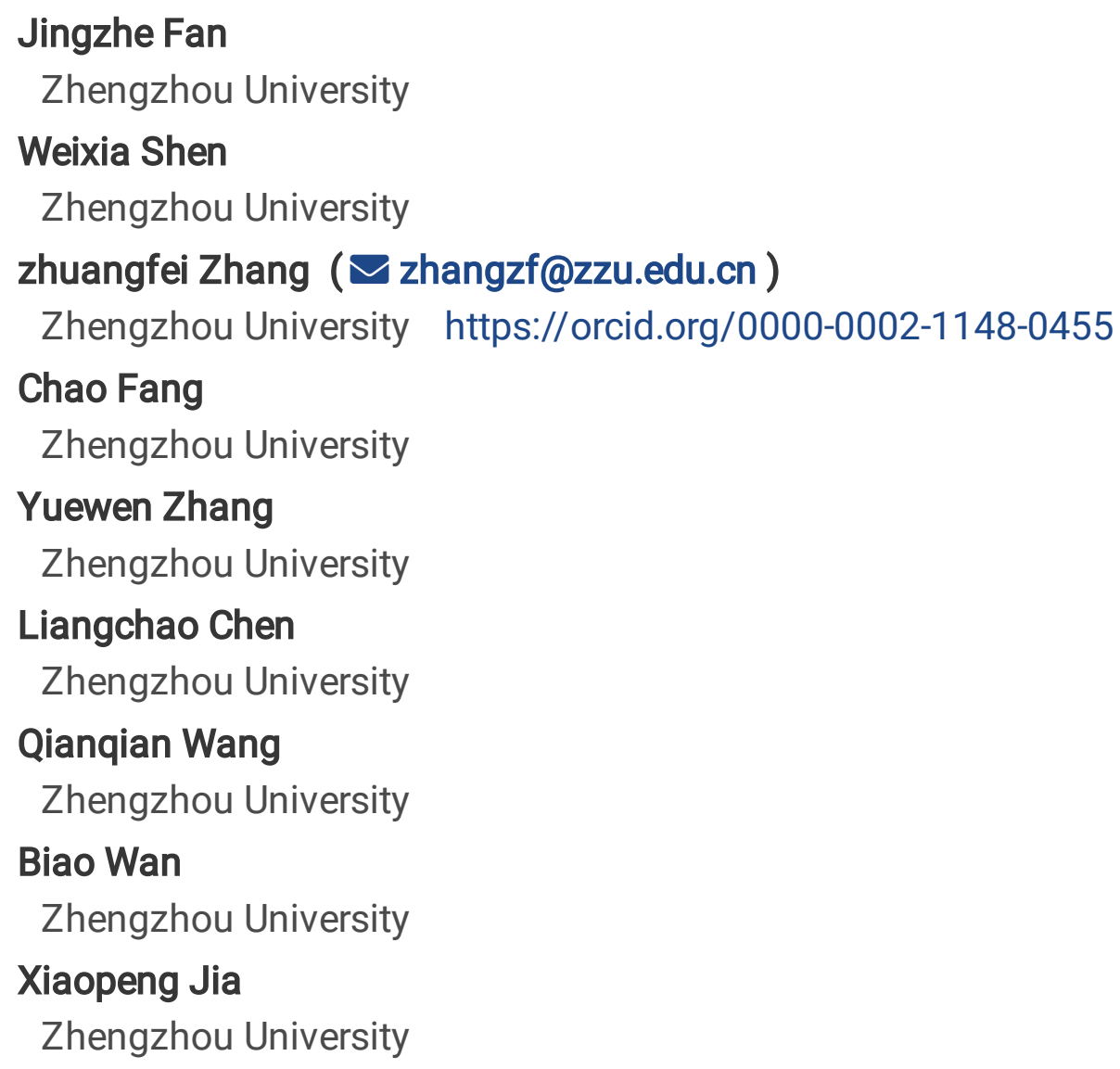

\section{Research Article}

Keywords: Boron carbide ceramics, Conductivity, Hardness, Fracture toughness

Posted Date: September 28th, 2020

DOI: https://doi.org/10.21203/rs.3.rs-81425/v1

License: (c) (1) This work is licensed under a Creative Commons Attribution 4.0 International License. Read Full License 
Dear Editor and Referees,

We would like to submit the enclosed manuscript entitled "Preparation and properties of $\mathrm{B}_{4} \mathrm{C}$ - $\mathrm{TiB}_{2}$ ceramics prepared by spark plasma sintering", which we wish to be considered for publication in Journal of advanced ceramics.

The paper is original and unpublished, and is not being or having been submitted for publication to any other journal, and that all the authors have read the paper and agree with its submission to Journal of advanced ceramics.

This manuscript was edited for proper English language, grammar, punctuation, spelling, and overall style by one or more of the highly qualified native English speaking editors at NativeEE. NativeEE specializes in editing and proofreading scientific manuscripts for submission to peer-reviewed journals.

The highlights are listed below:

- $\mathrm{B}_{4} \mathrm{C}-\mathrm{TiB}_{2}$ can be synthesized with spark plasma sintering.

- $\mathrm{TiH}_{2}$ contents can effectively increase the conductivity and the fracture toughness of $\mathrm{B}_{4} \mathrm{C}$.

- The electrical conductivity of $114.9 \mathrm{~S} / \mathrm{cm}$ is obtained, which is $100 \%$ higher than that of $\mathrm{B}_{4} \mathrm{C}$. 
I hope this paper is suitable for "Journal of advanced ceramics". We deeply appreciate your consideration of this manuscript.

Thank you and best regards.

Yours sincerely,

Zhuangfei Zhang and co-authors

School of Physics and Microelectronics, Zhengzhou University, Zhengzhou 450052, China

E-mail: zhangzf@zzu.edu.cn 


\section{Preparation and properties of}

\section{$\mathrm{B}_{4} \mathrm{C}-\mathrm{TiB}_{2}$ ceramics prepared by spark plasma sintering}

Jingzhe Fan ${ }^{\mathrm{a}}$, Weixia Shen ${ }^{\mathrm{a}}$, Zhuangfei Zhang ${ }^{\mathrm{a}^{*}}$, Chao Fang, Yuewen Zhanga, Liangchao Chen ${ }^{\mathrm{a}^{*}}$, Qianqian Wang ${ }^{\mathrm{a}}$, Biao Wan ${ }^{\mathrm{a}}$, Xiaopeng Jia ${ }^{\mathrm{a}^{*}}$

${ }^{a}$ Key Laboratory of Material Physics, Ministry of Education, School of Physics and Microelectronics, Zhengzhou University, Zhengzhou 450052, China.

Abstract: By doping titanium hydride $\left(\mathrm{TiH}_{2}\right)$ into boron carbide $\left(\mathrm{B}_{4} \mathrm{C}\right)$, a series of $\mathrm{B}_{4} \mathrm{C}+\mathrm{x}$ wt $\% \mathrm{TiH}_{2}(\mathrm{x}=0,5,10,15$ and 20) composite ceramics were obtained through spark plasma sintering (SPS). The effects of sintering temperature and the amount of $\mathrm{TiH}_{2}$ additive on the microstructure, mechanical and electrical properties of the sintered $\mathrm{B}_{4} \mathrm{C}-\mathrm{TiB}_{2}$ composite ceramics were investigated. Powder mixtures of $\mathrm{B}_{4} \mathrm{C}$ with $0-20 \mathrm{wt} \%$ $\mathrm{TiH}_{2}$ were heated from 1400 to $1800{ }^{\circ} \mathrm{C}$ for 20 minutes under $50 \mathrm{MPa}$. The results indicated that higher sintering temperatures contributed to greater ceramic density. With increasing $\mathrm{TiH}_{2}$ content, titanium diboride $\left(\mathrm{TiB}_{2}\right)$ formed between the $\mathrm{TiH}_{2}$ and $\mathrm{B}_{4} \mathrm{C}$ matrix. This effectively improved Young's modulus and fracture toughness of the composite ceramics, significantly improving their electrical properties: the electrical conductivity reached $114.9 \mathrm{~S} \cdot \mathrm{cm}^{-1}$ at $1800{ }^{\circ} \mathrm{C}$ when $\mathrm{x}=20$. Optimum mechanical properties were obtained for the $\mathrm{B}_{4} \mathrm{C}$ ceramics sintered with $20 \mathrm{wt} \% \mathrm{TiH}_{2}$, which had a relative density of $99.9 \pm 0.1 \%$, Vickers hardness of $31.8 \mathrm{GPa}$ and fracture toughness of 8.5 MPa $\mathrm{m}^{1 / 2}$. The results indicated that the doping of fine Ti particles into the $\mathrm{B}_{4} \mathrm{C}$ matrix increased the conductivity and the fracture toughness of $\mathrm{B}_{4} \mathrm{C}$. 
Keywords: Boron carbide ceramics; Conductivity; Hardness; Fracture toughness;

\section{Introduction}

With developments in science and technology, the research and application of ceramic composite materials have attracted increasing attention. Furthermore, due to the electrical conductivity of ceramics, they can be widely used as high-temperature electrothermal elements in oxidising atmospheres, as cathodes in high-temperature fuel cells (HTFC) and as electrodes for magnetohydrodynamic (MHD) power generation ${ }^{[1-2]}$. Traditional conductive ceramic materials, whether oxide or non-oxide ceramic materials, have low conductivity at room temperature. Therefore, the synthesis of conductive super-hard materials at room temperature would not only be of great scientific significance but also of great value for expanding the applications of ceramic materials.

The third hardest material known to man, black diamond, or $\mathrm{B}_{4} \mathrm{C}$ ceramic ${ }^{[3-4]}$, is an attractive ceramic because of its excellent properties such as low density $\left(2.51 \mathrm{~g} \cdot \mathrm{cm}^{-3}\right)$, high melting point $\left(2447{ }^{\circ} \mathrm{C}\right)$, high hardness (29-31 GPa), outstanding chemical stability and excellent absorption neutron cross-section $(600$ b). It has many applications, such as abrasive cutting, as a coating material, for light-weight armour and for controlling nuclear fission ${ }^{[5-6]} \cdot \mathrm{B}_{4} \mathrm{C}$ ceramic also has high Young's modulus (390-440 GPa) and low fracture toughness $\left(2.16-2.52 \mathrm{MPa} \cdot \mathrm{m}^{1 / 2}\right)^{[7-8]}$. Due to these characteristics, $\mathrm{B}_{4} \mathrm{C}$ ceramic is too difficult to sinter. However, $\mathrm{B}_{4} \mathrm{C}$ ceramic with high density can be obtained by pressureless sintering (PS) or hot pressing (HP) at above $2200{ }^{\circ} \mathrm{C}$, these conditions not only enable the grains to grow too easily but also waste 
thermal energy, which greatly limits $\mathrm{B}_{4} \mathrm{C}$ ceramic application ${ }^{[9-10]}$.

$\mathrm{TiB}_{2}$ is another super-hard material with high hardness $(34 \mathrm{GPa})$ and superconductivity $(14.4 \mu \Omega \cdot \mathrm{cm})$. It can be combined with $\mathrm{B}_{4} \mathrm{C}$ to form a composite material that results in inhibition of grain growth, lower sintering temperature and improved mechanical properties ${ }^{[11-17]}$. When sintered at high temperature, the overall performance of nanoscale $\mathrm{Ti}$ and $\mathrm{B}_{4} \mathrm{C}$ powders is weaker than that of pure $\mathrm{B}_{4} \mathrm{C}^{[18]}$. Additionally, Ti is easily oxidised into Ti-O phase, or Ti-B-O and Ti-C-O solid solutions. Nanoscale Ti powers are usually unstable, so they are too difficult to handle. Therefore, $\mathrm{TiH}_{2}$ has been used to disperse Ti particles in the $\mathrm{B}_{4} \mathrm{C}$ ceramic matrix to synthesise $\mathrm{TiB}_{2}$, thereby optimising its performance ${ }^{[19]}$. In addition, the fabrication of $\mathrm{B}_{4} \mathrm{C}-\mathrm{TiB}_{2}$ composite ceramics using $\mathrm{B}_{4} \mathrm{C}$ and $\mathrm{TiH}_{2}$ as starting materials by the spark plasma sintering (SPS) method has not yet been reported. The main aim of the present work was to synthesise $\mathrm{B}_{4} \mathrm{C}-\mathrm{TiB}_{2}$ composite ceramics and investigate the effect of $\mathrm{TiH}_{2}$ powders on the $\mathrm{B}_{4} \mathrm{C}$ ceramic properties.

\section{Materials and methods}

$\mathrm{B}_{4} \mathrm{C}$ powder $(99.5 \%, 1-10 \mu \mathrm{m})$ and $\mathrm{TiH}_{2}$ powder $(99 \%,-325 \mathrm{mesh})$ were purchased from Shanghai Aladdin Biochemical Technology, Shanghai, China and used as the starting materials ${ }^{[20]}$. Figure 1 shows the microstructures of these two raw materials. Powders composed of $\mathrm{B}_{4} \mathrm{C}$ and $\mathrm{TiH}_{2}(0,5,10,15,20 \mathrm{wt} \%)$ were mixed for more than 30 minutes in an agate mortar and then put into a graphite die $(40 \mathrm{~mm}$ in depth and 13.1 $\mathrm{mm}$ in diameter). The die was lined with graphite paper to separate the powders from 
graphite mould. The mixtures were sintered by SPS (LABOX-325R, Sinter Land Inc, Japan) under a uniaxial pressure of $50 \mathrm{MPa}$ in a vacuum. A schematic diagram of the sample preparation process and SPS is shown in Figure 2. Using a two-stage heating process, $\mathrm{TiH}_{2}{ }^{[21-23]}$ was first completely decomposed at $800{ }^{\circ} \mathrm{C}$ for 10 minutes and then heated to $1400,1500,1600,1700$ and $1800{ }^{\circ} \mathrm{C}$ for 20 minutes, each, at a heating rate of $100{ }^{\circ} \mathrm{C} \cdot \mathrm{min}^{-1}$. Figure 3 shows the temperature and displacement changes of the sample during $1800{ }^{\circ} \mathrm{C}$ sintering, revealing that the sample had a positive displacement and indicating that the sample was gradually densified.

After polishing the sintered $\mathrm{B}_{4} \mathrm{C}-\mathrm{TiB}_{2}$ composite ceramics, their density was determined using the Archimedes displacement method. The microstructures of the composite ceramics were characterised by X-Ray diffraction (XRD; X-pert, Japan) using $\mathrm{Cu}-\mathrm{Ka}$ radiation $(\lambda=1.5418 \AA$ ) and scanning electron microscopy (SEM; JSM-IT200(A), Japan). The elemental analysis of the $\mathrm{B}_{4} \mathrm{C}-\mathrm{TiB}_{2}$ composite ceramics was obtained by energy dispersive spectroscopy (EDS; JSM-IT200(A), Japan). The hardness of the $\mathrm{B}_{4} \mathrm{C}-\mathrm{TiB}_{2}$ composite ceramics was measured by a Vickers hardness tester (KB5-BVZ, Germany) with an applied load of $0.1-5 \mathrm{~N}$ for $10 \mathrm{~s}$ on the polished surface. The electrical performance was measured by a Hall effect measurement system (ECOPIA/HMS-5500, Korea). The shear and longitudinal velocities were measured by an ultrasound measurement system (OWON, 5072PR, China) to calculate Young s modulus, and then fracture toughness was calculated based on indentation crack length. 


\section{3 . Results and discussion}

\subsection{Density and Phase compositions}

The densities of $\mathrm{B}_{4} \mathrm{C}+\mathrm{x}$ wt $\% \mathrm{TiH}_{2}(\mathrm{x}=0,5,10,15,20)$ sintered at $1400,1500,1600$, 1700 and $1800{ }^{\circ} \mathrm{C}$ are shown in Table 1 . The results showed that the pure $\mathrm{B}_{4} \mathrm{C}$ ceramic reached complete densification at $1800{ }^{\circ} \mathrm{C}$ (the theoretical density of $\mathrm{B}_{4} \mathrm{C}$ is $2.51 \mathrm{~g} \cdot \mathrm{cm}^{-3}$ ). Figure 4 shows the density of $\mathrm{B}_{4} \mathrm{C}$ ceramics sintered with different $\mathrm{TiH}_{2}$ content at $1800{ }^{\circ} \mathrm{C}^{[24]}$, with increasing $\mathrm{TiH}_{2}$ content, the density of the composite ceramic reached a maximum at $20 \mathrm{wt} \% \mathrm{TiH}_{2}$. Both $\mathrm{TiB}_{2}$ and $\mathrm{C}$ can reduce sintering temperature and inhibit grain growth. Because $\mathrm{TiB}_{2}$ has relatively low crystalline boundary diffusion coefficient, which promotes slow densification ${ }^{[25]}$, graphite $(\mathrm{C})$ has a binding effect on grain boundary, which can enhance grain bounding diffusing and fast densification ${ }^{[26]}$. Therefore, the $\mathrm{B}_{4} \mathrm{C}-\mathrm{TiB}_{2}$ composite ceramics are densified well.

Figure 5 shows the XRD analysis of the $\mathrm{B}_{4} \mathrm{C}-\mathrm{TiB}_{2}$ composite ceramics doped with different $\mathrm{TiH}_{2}$ content and sintered at $1800{ }^{\circ} \mathrm{C}$ for 20 minutes. With increasing $\mathrm{TiH}_{2}$ content, the intensity of the $\mathrm{TiB}_{2}$ diffraction peaks (around $44^{\circ}$ ) continued to increase and reached a maximum with $20 \mathrm{wt} \% \mathrm{TiH}_{2}{ }^{[27]}$. Due to the decomposition of $\mathrm{TiH}_{2}$ powder at $620{ }^{\circ} \mathrm{C}$ via the process shown in Equation (1), the temperature was maintained at $800{ }^{\circ} \mathrm{C}$ for 10 minutes to ensure the complete formation of Ti. $\mathrm{B}_{4} \mathrm{C}$ is divided into $\mathrm{B}$ and $\mathrm{C}$ through the process shown in Equation (2), the presence of element $\mathrm{C}$ in the $\mathrm{XRD}$ pattern also confirms this statement. Ti and $\mathrm{B}$ form $\mathrm{TiB}_{2}$ through the process shown in Equation (3), The results indicated that an appropriate ratio of $\mathrm{B}_{4} \mathrm{C}$ 
and $\mathrm{TiH}_{2}$ could be completely converted into $\mathrm{B}_{4} \mathrm{C}-\mathrm{TiB}_{2}$ ceramics through the process shown in Equation (4) after sintering in SPS in a high vacuum environment. In this experiment, $\mathrm{TiB}_{2}$ was generated by the in situ reaction of $\mathrm{B}_{4} \mathrm{C}$ and $\mathrm{TiH}_{2}$, which can be described by the following three equations:

$$
\begin{gathered}
\mathrm{TiH}_{2} \rightarrow \mathrm{Ti}+\mathrm{H}_{2} \\
\mathrm{~B}_{4} \mathrm{C} \rightarrow 4 \mathrm{~B}+\mathrm{C} \\
\mathrm{Ti}+2 \mathrm{~B} \rightarrow \mathrm{TiB}_{2}
\end{gathered}
$$

The overall reaction can be summarised as follows:

$$
B_{4} \mathrm{C}+2 \mathrm{TiH}_{2}=2 \mathrm{TiB}_{2}+\mathrm{C}+2 \mathrm{H}_{2} \uparrow
$$

Figure 6 (a)-(f) shows images of the microstructure of $\mathrm{B}_{4} \mathrm{C}-\mathrm{TiB}_{2}$ composite ceramics containing different $\mathrm{TiH}_{2}$ content. The content of second-phase $\mathrm{TiB}_{2}$ increased with increasing $\mathrm{TiH}_{2}$ content. It was supposed that $\mathrm{Ti}$ originally existed at the brighter areas, and then the melted $\mathrm{Ti}$ reacted with $\mathrm{B}$ to form $\mathrm{TiB}_{2}$ in situ during sintering. Grain growth was not obvious in the $\mathrm{B}_{4} \mathrm{C}$ matrix as it was inhibited by the reaction of second-phase $\mathrm{TiB}_{2}$. When the content of $\mathrm{TiH}_{2}$ was increased to $20 \mathrm{wt} \%$, large-sized $\mathrm{TiB}_{2}$ grains of about 3-4 $\mu \mathrm{m}$ appeared with inhomogeneous distribution in the microstructure, as shown in Figure 6 (e), these could aggregate into 30-40 $\mu \mathrm{m}$ grains. The reaction between $\mathrm{Ti}$ and $\mathrm{B}$ is highly exothermic in behaviour and the heat generated helps to accelerate the formation of $\mathrm{TiB}_{2}$ readily. The primary $\mathrm{TiB}_{2}$ particles on the surface of $\mathrm{B}_{4} \mathrm{C}$ are appreciably free and movable and because of boron diffusion across boundary layer, $\mathrm{TiB}_{2}$ particles produces growth with the primary ones formed agglomerates ${ }^{[28]}$. 
Figure 7 shows the results of energy-dispersive X-ray spectroscopy (EDS) of part A in Figure 6 (f). Figure 7 (a) is an enlarged image of A, and the elemental content and distribution of A are shown in Figure 7 (b)-(f). XRD results combined with EDS spectra confirmed the phase distribution and that the light grey phase ${ }^{[29]}$ was $\mathrm{TiB}_{2}$, which has excellent electrical conductivity.

Figure 8 shows the EDS analysis of part B in Figure 6 (f). Figure 8 (a) is an enlarged image of $\mathrm{B}$, and the elemental content and distribution of $\mathrm{B}$ are shown in Figure 8 (b)-(f). XRD results combined with EDS spectra confirmed that the phase distribution of the matrix was $\mathrm{B}_{4} \mathrm{C}$, which has poor electrical conductivity.

\subsection{Hardness and fracture toughness}

The mechanical properties of $\mathrm{B}_{4} \mathrm{C}-\mathrm{TiB}_{2}$ were measured on the polished surface, as displayed in Figure $9^{[30-31]}$. The hardness-load curve of $\mathrm{B}_{4} \mathrm{C}-20 \mathrm{wt} \% \mathrm{TiH}_{2}$ is shown in Figure 9(a), revealing the obvious decrease in Vickers hardness (Hv) with increasing applied force, which was primarily attributed to the indentation size effect. An asymptotic $\mathrm{Hv}$ value of $\sim 31.4 \mathrm{GPa}$ was obtained when the applied load exceeded $5 \mathrm{~N}$. It may be because the hardness of $\mathrm{TiB}_{2}$ generated by the reaction is $34 \mathrm{GPa}$, and the hardness of $\mathrm{C}$ produced by the reaction is poor, which hardness is $1 \sim 2 \mathrm{GPa}^{[32-33]}$, the hardness of $\mathrm{B}_{4} \mathrm{C}$ is $31 \mathrm{GPa}$, which hardness is between $\mathrm{TiB}_{2}$ and $\mathrm{C}$. However, the results indicate that due to very little $\mathrm{C}$ produced by the reaction, the hardness of $\mathrm{B}_{4} \mathrm{C}-\mathrm{TiB}_{2}$ composite ceramics does not decrease under the combined action of $\mathrm{TiB}_{2}$ and $\mathrm{C}$. Vickers hardness and fracture toughness results for the $\mathrm{B}_{4} \mathrm{C}-\mathrm{TiB}_{2}$ composite ceramics are shown 
in Figure 9(b). When doped with $20 \mathrm{wt} \% \mathrm{TiH}_{2}$, the hardness of the sample was stable and the fracture toughness was a maximum of $8.5 \mathrm{MPa} \cdot \mathrm{m}^{1 / 2} \cdot \mathrm{TiB}_{2}$ is a high-toughness material, and $\mathrm{C}$ also can be used as an additive to produce high-toughness ceramic ${ }^{[34-37]}$, so the fracture toughness of $\mathrm{B}_{4} \mathrm{C}-\mathrm{TiB}_{2}$ composite ceramics are improved.

To calculate fracture toughness, an oscilloscope was used to measure the shear and longitudinal wave sound velocities and then the Poisson ratio $\mu$ was calculated using Equation (5). Data for the Young's modulus calculation was then obtained using Equation (6). Finally, the fracture toughness of the $\mathrm{B}_{4} \mathrm{C}-\mathrm{TiB}_{2}$ composite ceramics was calculated according to Equation (7).

The crack trace of the polished surface of the $20 \mathrm{wt} \% \mathrm{TiH}_{2}$ composite ceramic is shown in Figure 10. Crack bridging, crack deflection, crack bending and crack forking occurred when force was applied, and these cracks acted as tougheners for consuming energy. Crack bridging is helpful to improve fracture toughness ${ }^{[38]}$. The following three formulas were applied to calculate fracture toughness:

$$
\begin{gathered}
\mu=\frac{\frac{1}{2}\left(\frac{V_{L}}{V_{T}}\right)^{2}-1}{\left(\frac{V_{L}}{V_{T}}\right)^{2}-1} \\
E=\frac{V_{L}^{2} \times \rho \times(1-\mu) \times(1-2 \mu)}{1-\mu} \\
K_{I C}=0.016 \times\left(\frac{E}{H_{V}}\right)^{\frac{1}{2}} \times \frac{P}{C^{\frac{3}{2}}}
\end{gathered}
$$

\subsection{Electrical conductivity}

The electrical conductivity of the $\mathrm{B}_{4} \mathrm{C}+\mathrm{x}$ wt $\% \mathrm{TiH}_{2}(\mathrm{x}=0,5,10,15,20)$ composite 
ceramics at different sintering temperatures $\left(1400,1500,1600,1700\right.$ and $\left.1800{ }^{\circ} \mathrm{C}\right)$ is shown in Figure 11. The electrical conductivity could be enhanced by increasing the sintering temperature and increasing the content of $\mathrm{TiH}_{2}$. When doped with $5 \mathrm{wt} \%$ or 10 wt $\% \mathrm{TiH}_{2}$, the electrical conductivity of the $\mathrm{B}_{4} \mathrm{C}-\mathrm{TiB}_{2}$ composite ceramics suddenly increased. When $\mathrm{TiH}_{2}$ was further increased to $15 \mathrm{wt} \%$ or $20 \mathrm{wt} \%$, the electrical conductivity of the $\mathrm{B}_{4} \mathrm{C}-\mathrm{TiB}_{2}$ composite ceramics was two orders of magnitude higher than that of pure $\mathrm{B}_{4} \mathrm{C}$. At room temperature, a maximum electrical conductivity of 114.9 $\mathrm{S} \cdot \mathrm{cm}^{-1}$ was achieved with $20 \mathrm{wt} \% \mathrm{TiH}_{2}$. Graphite is one type of carbon-based filler, due to being layered structure, its electrical conductivity is $10^{4} \mathrm{~S} / \mathrm{cm}$ at room temperature ${ }^{[39]}$. Ti reacted with $\mathrm{B}$ to form $\mathrm{TiB}_{2}$, the layered structure of boron atoms similar to graphite and the outer electrons of $\mathrm{Ti}$ determine the outstanding electrical conductivity of $\mathrm{TiB}_{2}$, they can be used for improving the electrical conductivity of composite ceramics.

\section{Conclusions}

Completely densified $\mathrm{B}_{4} \mathrm{C}-\mathrm{TiB}_{2}$ composite ceramics with high conductivity, high strength and high hardness properties were successfully obtained by the spark plasma sintering method starting from raw mixtures of $\mathrm{B}_{4} \mathrm{C}$ and $\mathrm{TiH}_{2}$ powders. Using $\mathrm{TiH}_{2}$ as a sintering aid improved the density of the $\mathrm{B}_{4} \mathrm{C}$ ceramics. During the sintering process, $\mathrm{B}_{4} \mathrm{C}$ reacted with Ti to form $\mathrm{TiB}_{2}$ and a small amount of $\mathrm{C}$, which successfully inhibited the growth of $\mathrm{B}_{4} \mathrm{C}$ and improved the electrical conductivity, Young modulus and fracture toughness. 


\section{Acknowledgements}

This work was supported by the National Natural Science Foundation of China (No. 11704340 and 11804305), and The Scientific and Technology project in Henan Province (No. 202102210198).

\section{References}

[1] An LQ, Wang LY, Wang LF, Fan RH, Ito A, Goto T. Fabrication of $\mathrm{Lu}_{2} \mathrm{Ti}_{2} \mathrm{O}_{7}-\mathrm{Lu}_{3} \mathrm{NbO}_{7}$ solid solution transparent ceramics by spark plasma sintering and their electrical conductivities. J Eur Ceram Soc 2020, 40: 4589-4594. https://doi.org/10.1016/j.jeurceramsoc.2020.05.008.

[2] Grigoriev SN, Volosova MA, Peretyagin PY, Seleznev AE, Okunkova AA, Smirnov

A. The effect of TiC additive on mechanical and electrical properties of $\mathrm{Al}_{2} \mathrm{O}_{3}$ ceramic. Appl Sci-Basel 2018, 8: 2385-8387. https://doi.org/10.3390/app8122385.

[3] Domnich V, Reynaud S, Haber RA, Chhowalla M. Boron Carbide: Structure, Properties, and Stability under Stress. J Am Ceram Soc 2011, 94: 3605-3628. https://doi.org/10.1111/j.1551-2916.2011.04865.x.

[4] Jamale S, Kumar BVM. Sintering and sliding wear studies of $\mathrm{B}_{4} \mathrm{C}-\mathrm{SiC}$ composites. Int J Refract Met H 2020, 87: 105124. https://doi.org/10.1016/j.ijrmhm.2019.105124.

[5] He Y, Shen YD, Tang B, An Q. Enhanced strength and ductility of superhard boron carbide through injecting electrons. J Eur Ceram Soc 2020, 40: 4428-4435. https://doi.org/10.1016/j.jeurceramsoc.2020.06.004.

[6] Zhang W, Yamashita S, Kita H. Progress in pressureless sintering of boron carbide 
ceramics-a review. ADV Appl Ceram 2019, 118: 222-239. https://doi.org/10.1080/17436753.2019.1574285.

[7] Badica P, Grasso S, Borodianska H, Xie SS, Li PF, Takarko P, Reece MJ, Sakka Y, Vasylkiv O. Tough and dense boron carbide obtained by high-pressure (300 MPa) and low-temperature $\left(1600{ }^{\circ} \mathrm{C}\right)$ spark plasma sintering. J Ceram Soc Jpn 2014, 122: 271-275. https://doi.org/10.2109/jcersj2.122.271.

[8] K. Sairam, J.K. Sonber, T.S.R.C. Murthy, C. Subramanian, R.K. Fotedar, P. Nanekar, R.C. Hubli, Influence of spark plasma sintering parameters on densification and mechanical properties of boron carbide, Int. J. Refract. Met. H. 42 (2014) 182-192. https://doi.org/10.1016/j.ijrmhm.2013.09.004.

[9] Singh P, Singh B, Kumar M, Kumar A. One step reduction of Boric Acid to boron carbide nanoparticles. Ceram Int 2014, 40: 15331-15334. https://doi.org/10.1016/j.ceramint.2014.06.101.

[10] Moskovskikh DO, Paramonov KA, Nepapushev AA, Shkodich NF, Mukasyan AS. Bulk boron carbide nanostructured ceramics by reactive spark plasma sintering. Ceram Int 2017, 43: 8190-8194. https://doi.org/ 10.1016/j.ceramint.2017.03.145.

[11] Heydari MS, Baharvandi HR. Comparing the effects of different sintering methods for ceramics on the physical and mechanical properties of $\mathrm{B}_{4} \mathrm{C}-\mathrm{TiB}_{2}$ nanocomposites. Int J Refract Met H 2015, 51: 224-232. https://doi.org/10.1016/j.ijrmhm.2015.04.003.

[12] Heydari MS, Baharvandi HR. Effect of different additives on the sintering ability and the properties of $\mathrm{B}_{4} \mathrm{C}-\mathrm{TiB}_{2}$ composites. Int $\mathrm{J}$ Refract Met $\mathrm{H}$ 2015, 51: 61-69. 
https://doi.org/10.1016/j.ijrmhm.2015.02.014.

[13] White RM, Dickey EC. Mechanical properties and deformation mechanisms of $\mathrm{B}_{4} \mathrm{C}-\mathrm{TiB}_{2}$ eutectic composites. $\mathrm{J}$ Eur Ceram Soc 2014, 34: 2043-2050. https://doi.org/10.1016/j.jeurceramsoc.2013.08.012.

[14] Gao YB, Tang TG, Yi CH, Zhang W, Li DC, Xie WB, Huang W, Ye N. Study of static and dynamic behavior of $\mathrm{TiB}_{2}-\mathrm{B}_{4} \mathrm{C}$ composite. Mater Design 2016, 92: 814-822. https://doi.org/10.1016/j.matdes.2015.12.123.

[15] He QL, Wang AY, Liu C, Wang WM, Wang H, Fu ZY. Microstructures and mechanical properties of $\mathrm{B}_{4} \mathrm{C}-\mathrm{TiB}_{2}-\mathrm{SiC}$ composites fabricated by ball milling and hot $\begin{array}{llllll}\text { pressing. } & \mathrm{J} & \text { Eur } & \text { Ceram } & \text { Soc } & \text { 2018, }\end{array}$ https://doi.org/10.1016/j.jeurceramsoc.2018.02.020.

[16] Yue XY, Zhao SM, Lu P, Chang Q, Ru HQ. Synthesis and properties of hot pressed $\mathrm{B}_{4} \mathrm{C}-\mathrm{TiB}_{2}$ ceramic composite. Mat Sci Eng A-Struct 2010, 527: 7215-7219. https://doi.org/10.1016/j.msea.2010.07.101.

[17] White RM, Kunkle JM, Polotai AV, Dickey EC. Microstructure and hardness scaling in laser-processed $\mathrm{B}_{4} \mathrm{C}-\mathrm{TiB}_{2}$ eutectic ceramics. J Eur Ceram Soc 2011, 31: 1227-1232. https://doi.org/10.1016/j.jeurceramsoc.2010.06.013.

[18] Karimoto T, Nishimoto A. Simultaneous Boronizing and Carburizing of Titanium via Spark Plasma Sintering. Mater Trans 2019, 60: 2387-2391. https://doi.org/10.2320/matertrans.L-M2019838.

[19] Shi SF, Cho SH, Goto T, Sekino T. Fine Ti-dispersed $\mathrm{Al}_{2} \mathrm{O}_{3}$ composites and their 
mechanical and electrical properties. J Am Ceram Soc 2018, 101: 3181-3190. https://doi.org/10.1111/jace.15472.

[20] Tan YQ, Chen C, Li FZ, Zhang HB, Zhang GJ, Peng SM. Enhancement of sinterability and mechanical properties of $\mathrm{B}_{4} \mathrm{C}$ ceramics using $\mathrm{Ti}_{3} \mathrm{AlC}_{2}$ as a sintering aid. RSC Adv 2015, 5: 76309-76314. https://doi.org/10.1039/c5ra14191e.

[21] Pan Y, Chen S. Exploring the novel structure, transportable capacity and thermodynamic properties of $\mathrm{TiH}_{2}$ hydrogen storage material. Int J Energ Res 2020, 44: 4997-5007. https://doi.org/10.1002/er.5260.

[22] Ito M, Setoyama D, Matsunaga J, Muta H, Kurosaki K, Uno M, Yamanaka S. Electrical and thermal properties of titanium hydrides. J Alloy Compd 2006, 420: 25-28. https://doi.org/10.1016/j.jallcom.2005.10.032.

[23] Liu H, He P, Feng JC, Cao J. Kinetic study on nonisothermal dehydrogenation of $\mathrm{TiH}_{2}$ powders. Int J Hydrogen Energ 2009, 34: 3018-3025. https://doi.org/10.1016/j.ijhydene.2009.01.095.

[24] Rehman SS, Ji W, Khan SA, Fu ZY, Zhang F. Microstructure and mechanical properties of $\mathrm{B}_{4} \mathrm{C}$ densified by spark plasma sintering with $\mathrm{Si}$ as a sintering aid. Ceram Int 2015, 41: 1903-1906. https://doi.org/10.1016/j.ceramint.2014.09.115.

[25] Pei LZ, Xiao HN. $\mathrm{B}_{4} \mathrm{C} / \mathrm{TiB}_{2}$ composite powders prepared by carbothermal reduction method. J Mater Process Tech 2009, 209: 2122-2128. https://doi.org/10.1016/j.jmatprotec.2008.05.003.

[26] Yin BY, Wang LS, Fang YC. Sintering mechanism of pure and carbon-doped boron 
$\begin{array}{llllll}\text { carbide. } & \text { J } & \text { Chin } & \text { Ceram } & \text { Soc } & \text { 2001, }\end{array}$ https://doi.org/10.14062/j.issn.0454-5648.2001.01.015.

[27] Yin SP, Zhang ZH, Cheng XW, Su TJ, Hu ZY, Song Q, Wang H. Spark plasma sintering of $\mathrm{B}_{4} \mathrm{C}-\mathrm{TiB}_{2}-\mathrm{SiC}$ composite ceramics using $\mathrm{B}_{4} \mathrm{C}, \mathrm{Ti}_{3} \mathrm{SiC}_{2}$ and $\mathrm{Si}$ as starting $\begin{array}{lllll}\text { materials. } & \text { Ceram } & \text { Int } & \text { 201626-21632. }\end{array}$ https://doi.org/10.1016/j.ceramint.2018.08.245.

[28] Suresh S, Moorthi NSV. Aluminium- titanium diboride (Al-TiB2) metal matrix composites: challenges and opportunities. Procedia Eng 2012, 38: 89-97. https://doi.org/10.1016/j.proeng.2012.06.013.

[29] Wen Q, Tan YQ, Zhong ZH, Zhang HB, Zhou XS. High toughness and electrical discharge machinable $\mathrm{B}_{4} \mathrm{C}-\mathrm{TiB}_{2}-\mathrm{SiC}$ composites fabricated at low sintering temperature. Mat Sci Eng A-Struct 2017, 701: 338-343. https://doi.org/10.1016/j.msea.2017.06.100. [30] Anstis GR, Chantikui P, Lawn BR, Marshall DB. A critical evaluation of indentation techniques for measuring fracture toughness: 1. direct crack measurements. J Am Ceram Soc 1981, 64: 533-538. https://doi.org/ 10.1111/j.1151-2916.1981.tb10320.x.

[31] Ma DJ, Wang JL, Sun L. Methodology for measuring fracture toughness of ceramic materials by instrumented indentation test with vickers indenter. J Am Ceram Soc 2017, 100: 2296-2308. https://doi.org/10.1111/jace.14650.

[32] Sengupta R, Bhattacharya M, Bandyopadhyay S, Bhowmick AK. A review on the mechanical and electrical properties of graphite and modified graphite reinforced 
polymer composites. Prog Polym Sci 2011, 36: 638-670. https://doi.org/10.1016/j.propolymsci.2010.11.003.

[33] Oku T, Kurumada A, Imamura Y, Ishihara M. Effects of ionirradiation on the hardness properties of graphites and $\mathrm{C} / \mathrm{C}$ composites by indentation tests. J Mucl Mater 2008, 381: 92-97. https://doi.org/10.1016/j.jnucmat.2008.07.026.

[34] Peng C, Tang H, He Y, Lu XQ, Jia P, Liu GY, Zhao YC, Wang MZ. A novel non-stoichiometric medium-entropy carbide stabilized by anion vacancies. J Mater Sci Technol 2020, 51: 161-166. https://doi.org/10.1016/j.jmst.2020.02.049.

[35] Skorokhod V, Krstic V. High strength-high toughness $\mathrm{B}_{4} \mathrm{C}-\mathrm{TiB}_{2}$ composites. J Mater Sci Lett 2000, 19: 237-9. https://doi.org/10.1023/A:1006766910536.

[36] Shi L, Li HY, Zou ZM, Fok ASL, Marsden BJ, Hodgkins A, Mummery PM, Marrow J. Analysis of crack propagation in nuclear graphite using three-point bending of sandwiched specimens. J Nucl Mater 2008, 372: 141-151. https://doi.org/10.1016/j.jnucmat.2007.02.012.

[37] Chen HHN, Su RKL, Fok SL, Zhang HG. Fracture behavior of nuclear graphite under three-point bending tests. Eng Fract Mech 2017, 186: 143-157. https://doi.org/10.1016/j.engfracmech.2017.09.030.

[38] Ouagne P, Neighbour GB, McEnaney B. Crack growth resistance in nuclear $\begin{array}{lllllll}\text { graphites. J } & \text { Phys } & \text { D: Appl Phys 2002, } & \text { 35: }\end{array}$ https://doi.org/10.1088/0022-3727/35/9/315.

[39] Reis JML, Martins SA, Mattos HSD. Combination of temperature and electrical 
conductivity on semiconductor graphite/epoxy composites. J Braz Soc Mech Sci 2020, 42: 8. https://doi.org/10.1007/s40430-020-02487-z. 


\begin{tabular}{llllll}
\hline Temperature $\left({ }^{\circ} \mathrm{C}\right)$ & $\mathbf{0 w t} \%$ & $\mathbf{5 w t} \%$ & $\mathbf{1 0 w t} \%$ & $\mathbf{1 5 w t} \%$ & $\mathbf{2 0 w t} \%$ \\
\hline 1400 & 2.20 & 1.83 & 1.85 & 2.04 & 2.06 \\
1500 & 2.23 & 2.12 & 2.03 & 2.34 & 2.28 \\
1600 & 2.27 & 2.25 & 2.17 & 2.54 & 2.51 \\
1700 & 2.42 & 2.36 & 2.51 & 2.59 & 2.52 \\
1800 & 2.51 & 2.57 & 2.62 & 2.74 & 2.83 \\
\hline
\end{tabular}

Table. 1. Density of monolithic $\mathrm{B}_{4} \mathrm{C}$ sintered from $1400{ }^{\circ} \mathrm{C}$ to $1800{ }^{\circ} \mathrm{C}$.
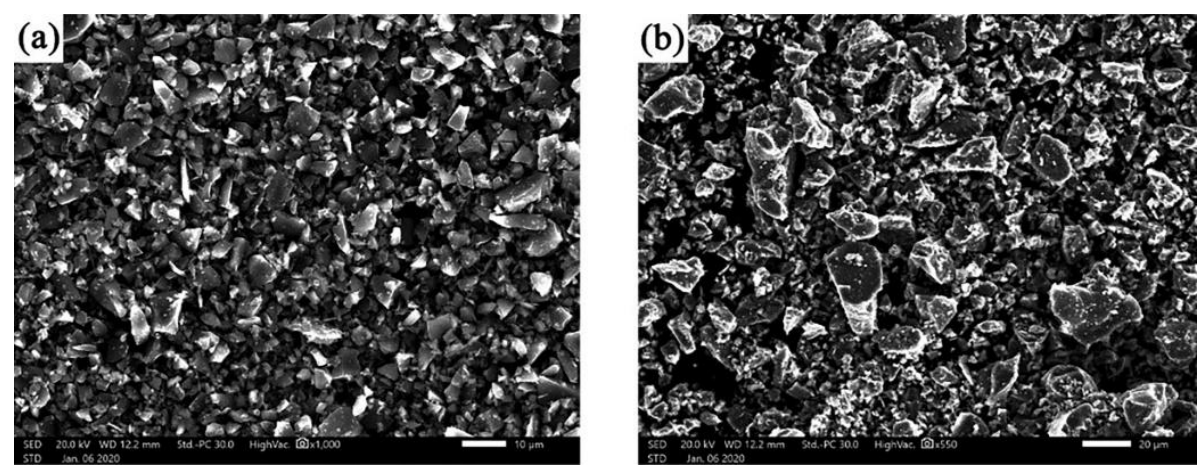

Fig.1. Microstructure of (a) $\mathrm{B}_{4} \mathrm{C}$ and (b) $\mathrm{TiH}_{2}$ powders.

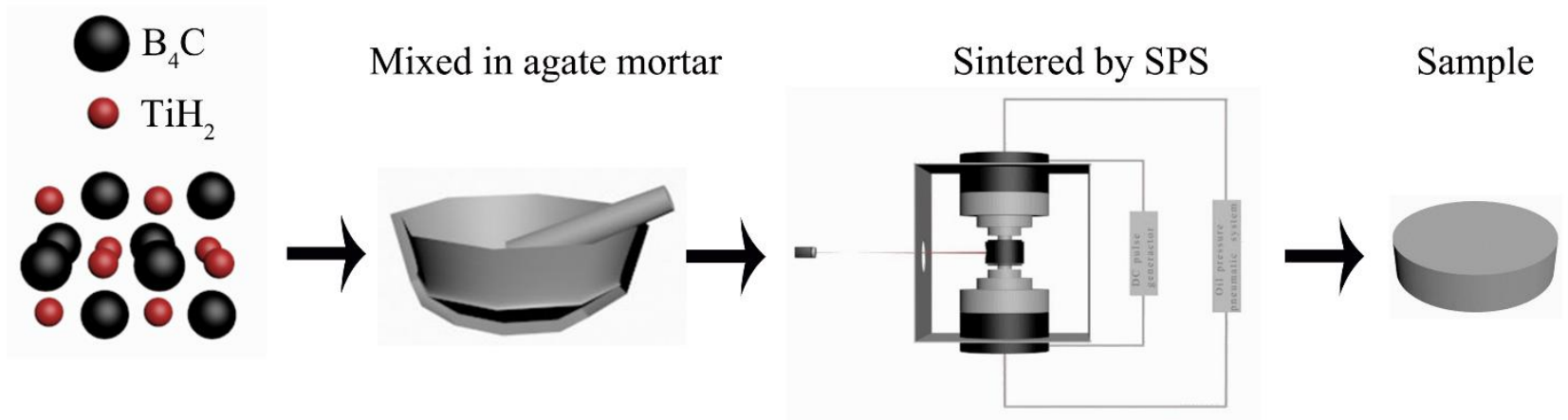

Fig.2. The procedure of sample sintering. 


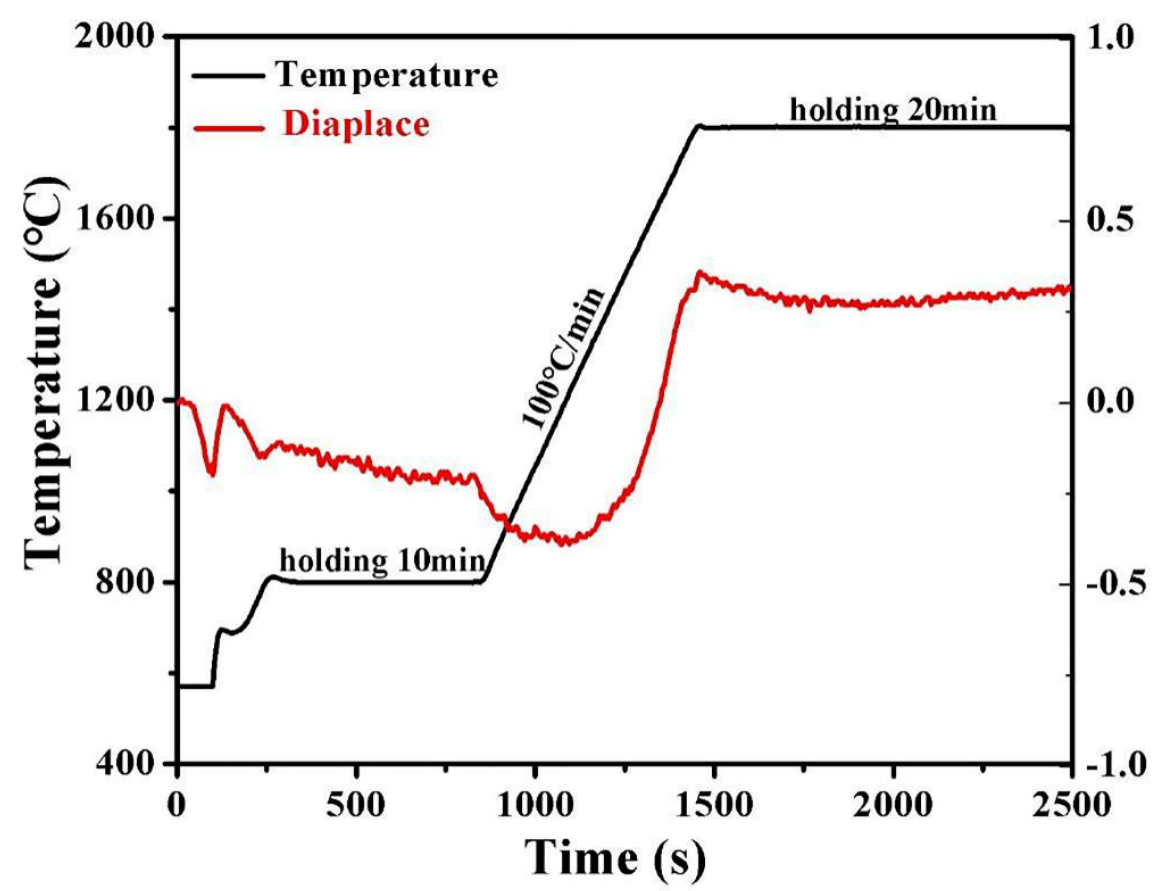

Fig.3. The temperature and displacement change at $1800^{\circ} \mathrm{C}$ with SPS.

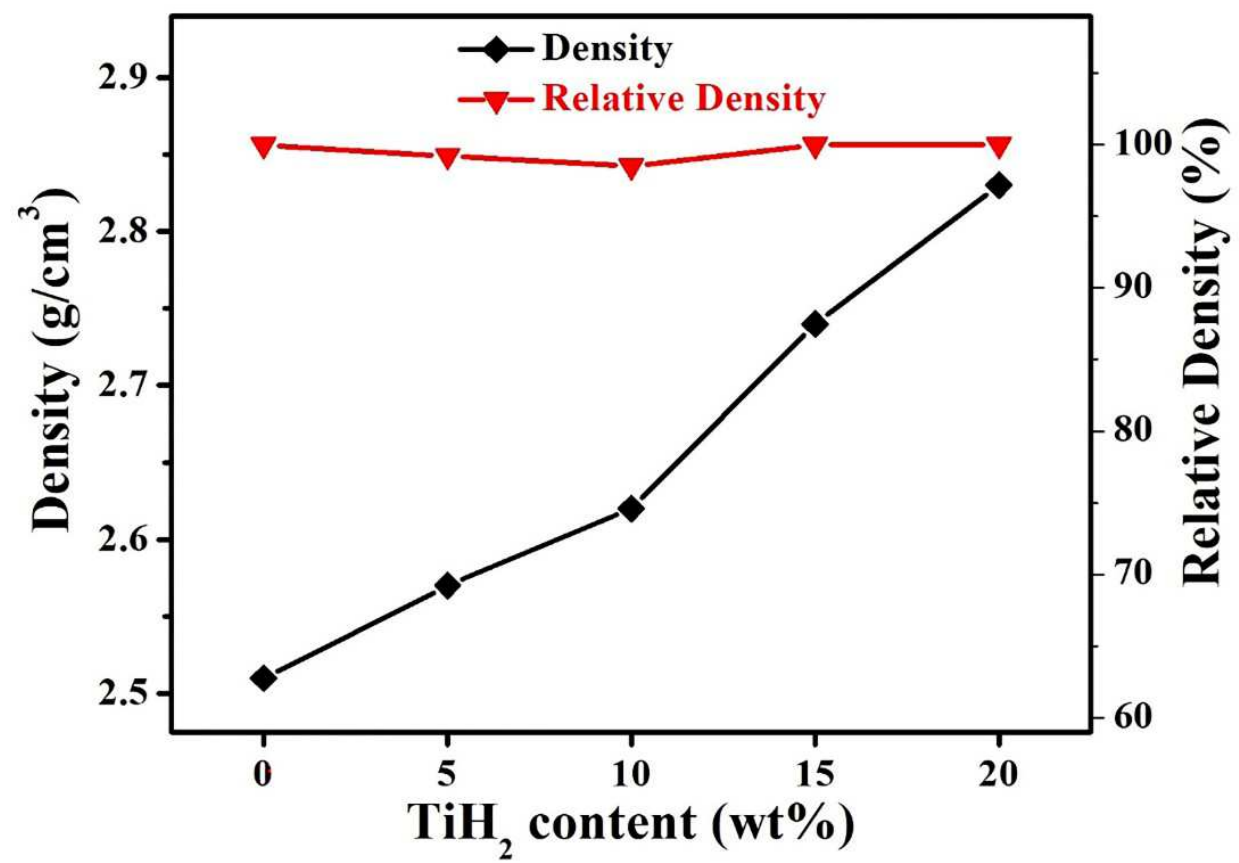

Fig. 4. Density of $\mathrm{B}_{4} \mathrm{C}$ specimens as a function of $(0-20) \mathrm{wt} \% \mathrm{TiH}_{2}$ content at $1800{ }^{\circ} \mathrm{C}$. 


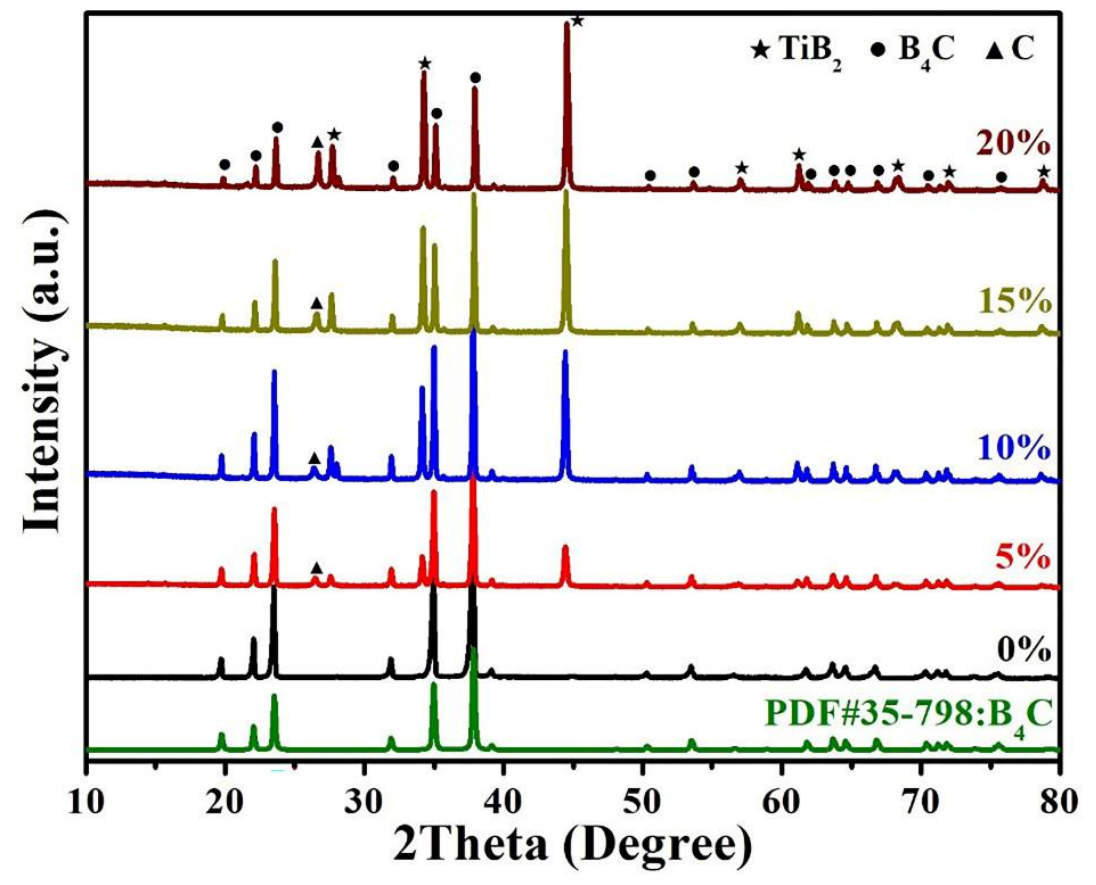

Fig.5. XRD patterns of the synthesized $\mathrm{B}_{4} \mathrm{C}+\mathrm{x}$ wt $\% \mathrm{TiH}_{2}(\mathrm{x}=0,5,10,15,20)$ composite ceramics.
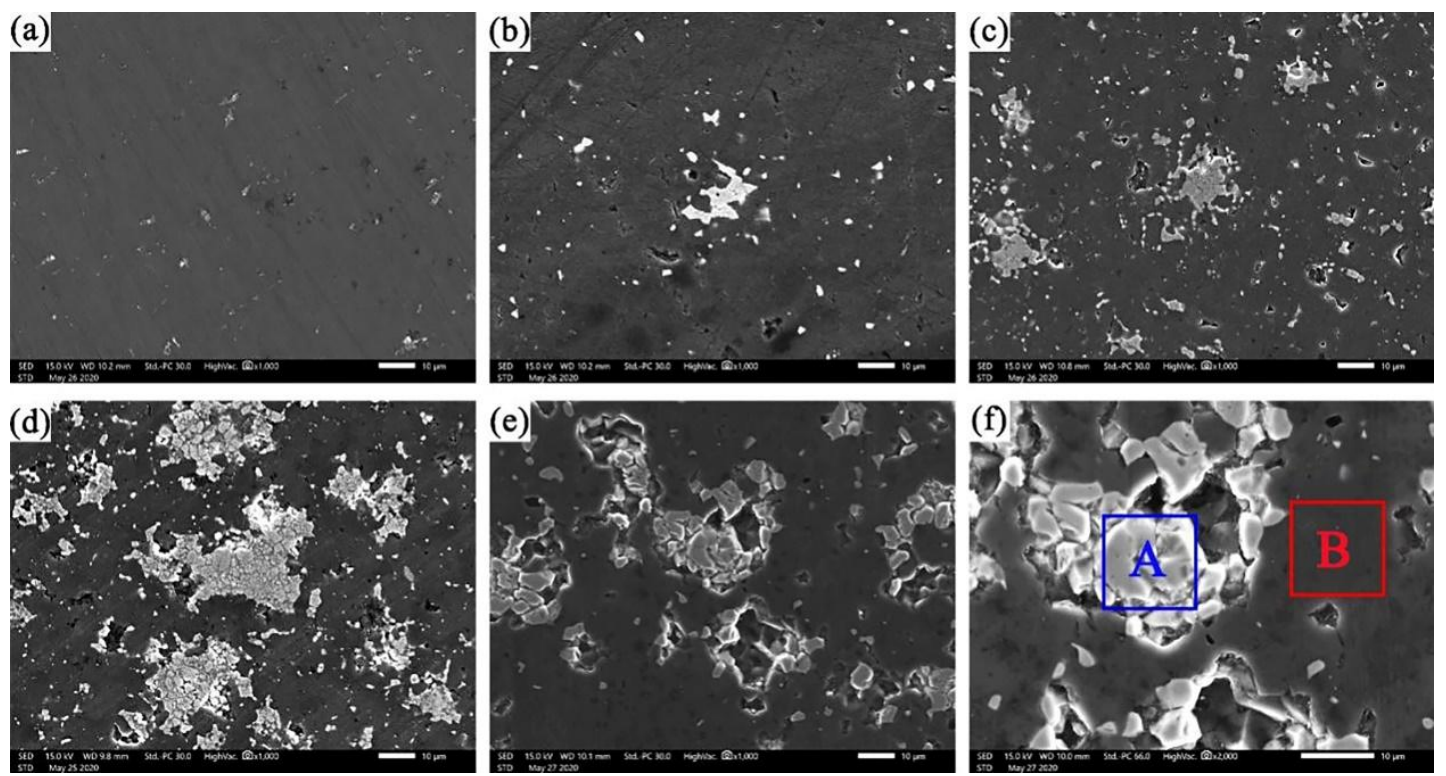

Fig.6. Polished surfaces of $\mathrm{B}_{4} \mathrm{C}$ ceramics sintered with different amount of $\mathrm{TiH}_{2}$ content

sintered at $1800{ }^{\circ} \mathrm{C}$. (a) $\mathrm{B}_{4} \mathrm{C}-0 \mathrm{wt} \% \mathrm{TiH}_{2}$; (b) $\mathrm{B}_{4} \mathrm{C}-5 \mathrm{wt} \% \mathrm{TiH}_{2}$; (c) $\mathrm{B}_{4} \mathrm{C}-10 \mathrm{wt} \% \mathrm{TiH}_{2}$; (d) $\mathrm{B}_{4} \mathrm{C}-15 \mathrm{wt} \%$

$\mathrm{TiH}_{2}$; (e) $\mathrm{B}_{4} \mathrm{C}-20 \mathrm{wt} \% \mathrm{TiH}_{2}$; (f) The enlarged view of $\mathrm{B}_{4} \mathrm{C}-20 \mathrm{wt} \% \mathrm{TiH}_{2}$. 
(a)

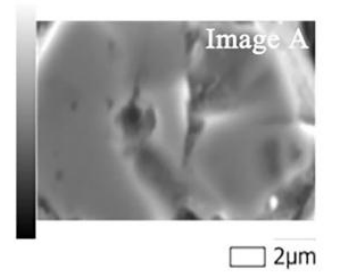

(e)

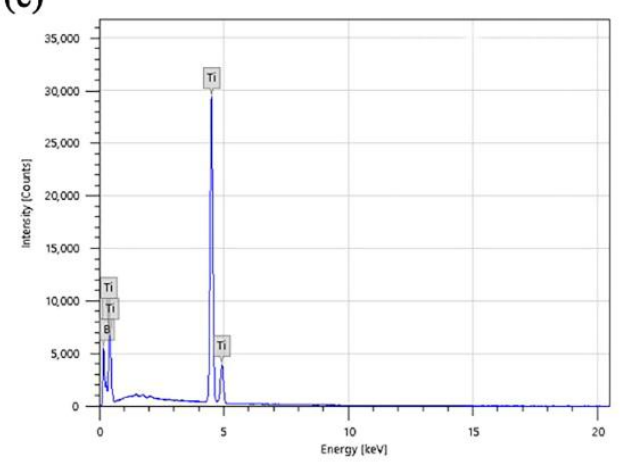

(c)
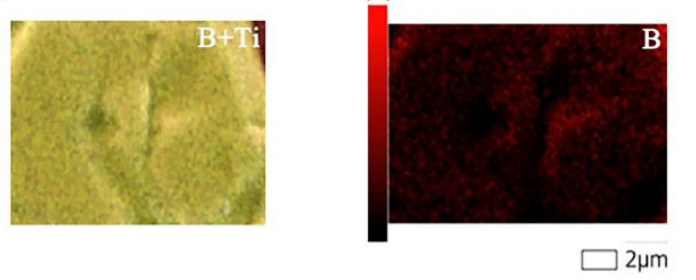

(d)

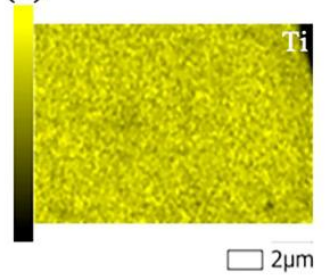

(f)

\begin{tabular}{|c|c|c|c|}
\hline Element & Line & Mass\% & Atom\% \\
\hline B & K & $36.00 \pm 0.04$ & $71.36 \pm 0.09$ \\
\hline Ti & K & $64.00 \pm 0.14$ & $28.64 \pm 0.06$ \\
\hline Total & & 100.00 & 100.00 \\
\hline
\end{tabular}

Fig.7. The related EDS spectra of A sintered with $20 \mathrm{wt} \%$ of $\mathrm{TiH}_{2}$ content sintered at $1800{ }^{\circ} \mathrm{C}$. (a)

EDS test area image A; (b) Ti-K,B-K; (c)B-K; (d)Ti-K; (e) EDS spectra of image A; (f) Element content of image A. 
(a)

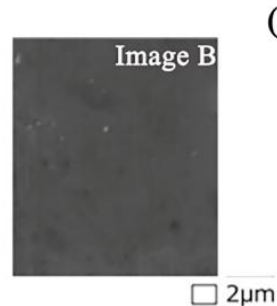

(e)

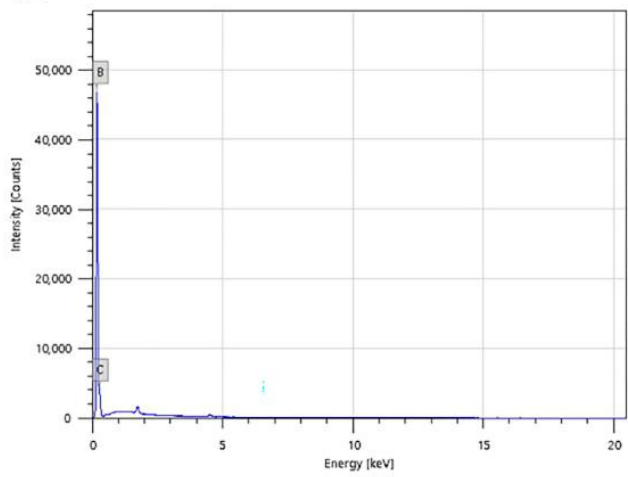

(c)

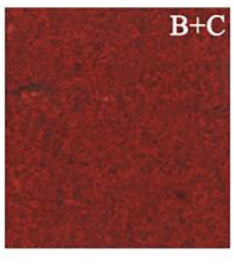

$2 \mu \mathrm{m}$

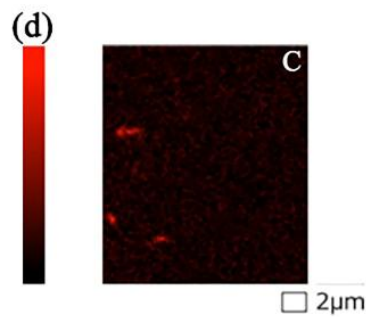

$\square 2 \mu \mathrm{m}$

\section{(f)}

\begin{tabular}{|c|c|c|c|}
\hline Element & Line & Mass\% & Atom \% \\
\hline B & K & $73.75 \pm 0.03$ & $75.74 \pm 0.03$ \\
\hline C & K & $26.25 \pm 0.09$ & $24.26 \pm 0.08$ \\
\hline Total & & 100.00 & 100.00 \\
\hline
\end{tabular}

Fig.8. The related EDS spectra of B sintered with $20 \mathrm{wt} \%$ of $\mathrm{TiH}_{2}$ content sintered at $1800{ }^{\circ} \mathrm{C}$ (a)

EDS test area image B; (b) B-K,C-K; (c)B-K; (d) C-K; (e) EDS spectra of image B; (f) Element content of image B.

(a)

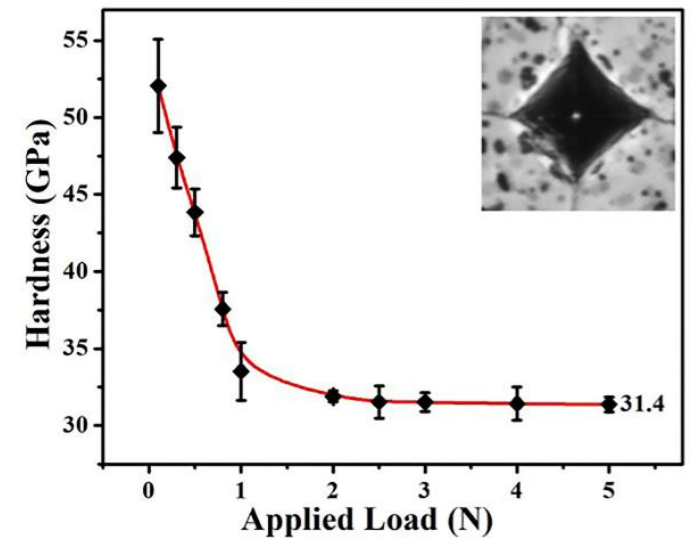

(b)

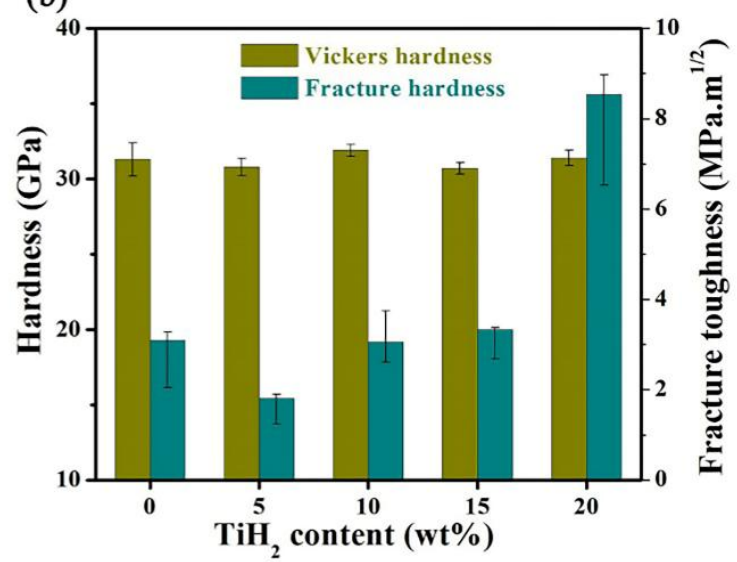

Fig. 9. Comparison of mechanical properties. (a) The measured Vickers hardness of $\mathrm{B}_{4} \mathrm{C}-20 \mathrm{wt} \%$

$\mathrm{TiH}_{2}$ under $5 \mathrm{~N}$ load at $1800^{\circ} \mathrm{C}$. (b) Effect of $\mathrm{TiH}_{2}$ addiction on the hardness and fracture toughness of $\mathrm{B}_{4} \mathrm{C}$ at $1800^{\circ} \mathrm{C}$ 

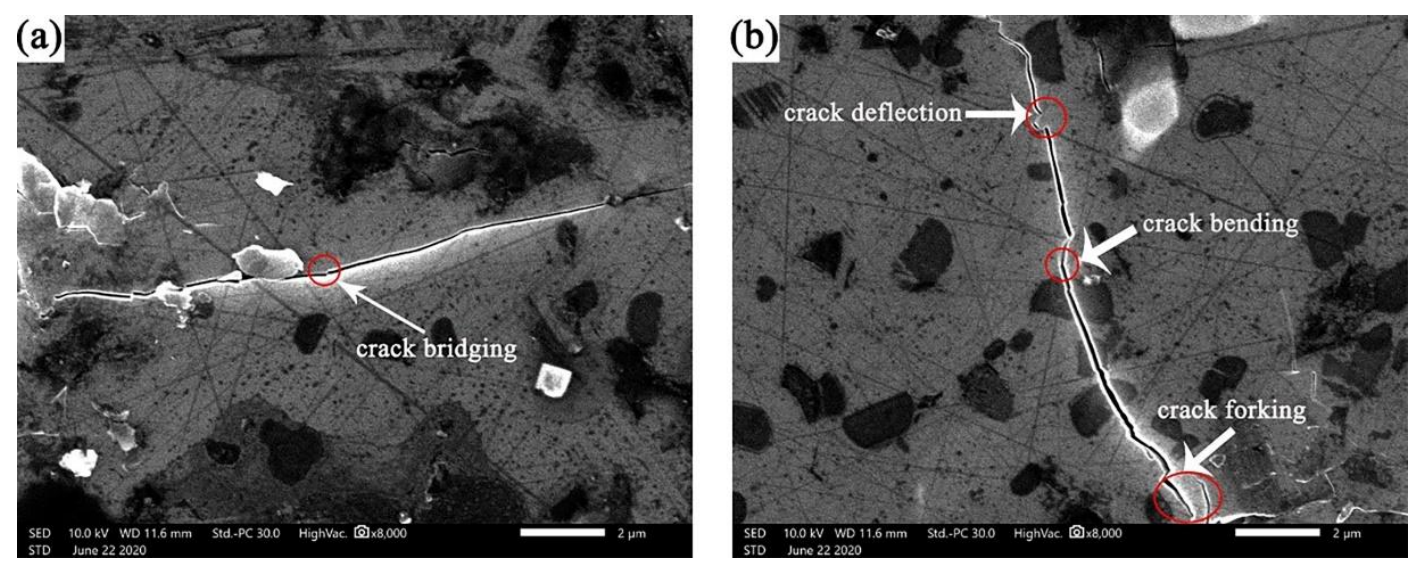

Fig.10. SEM micrographs of the polished surfaces cracks of the $\mathrm{B}_{4} \mathrm{C}-\mathrm{TiB}_{2}$ composite ceramics with $20 \mathrm{wt} \% \mathrm{TiH}_{2}$.

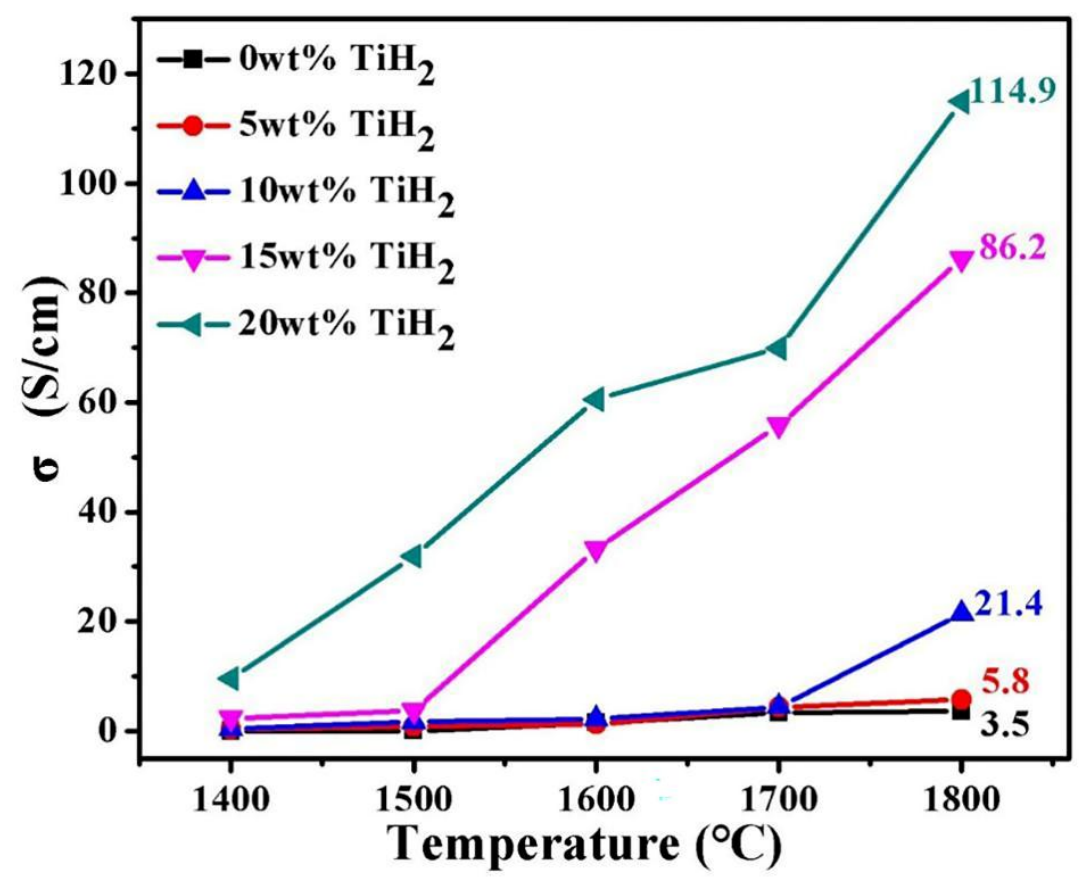

Fig. 11. The electrical conductivity of $\mathrm{B}_{4} \mathrm{C}-(0,5,10,15,20) \mathrm{wt} \% \mathrm{TiH}_{2}$ composite ceramics at different sintering temperature. 


\section{Figures}
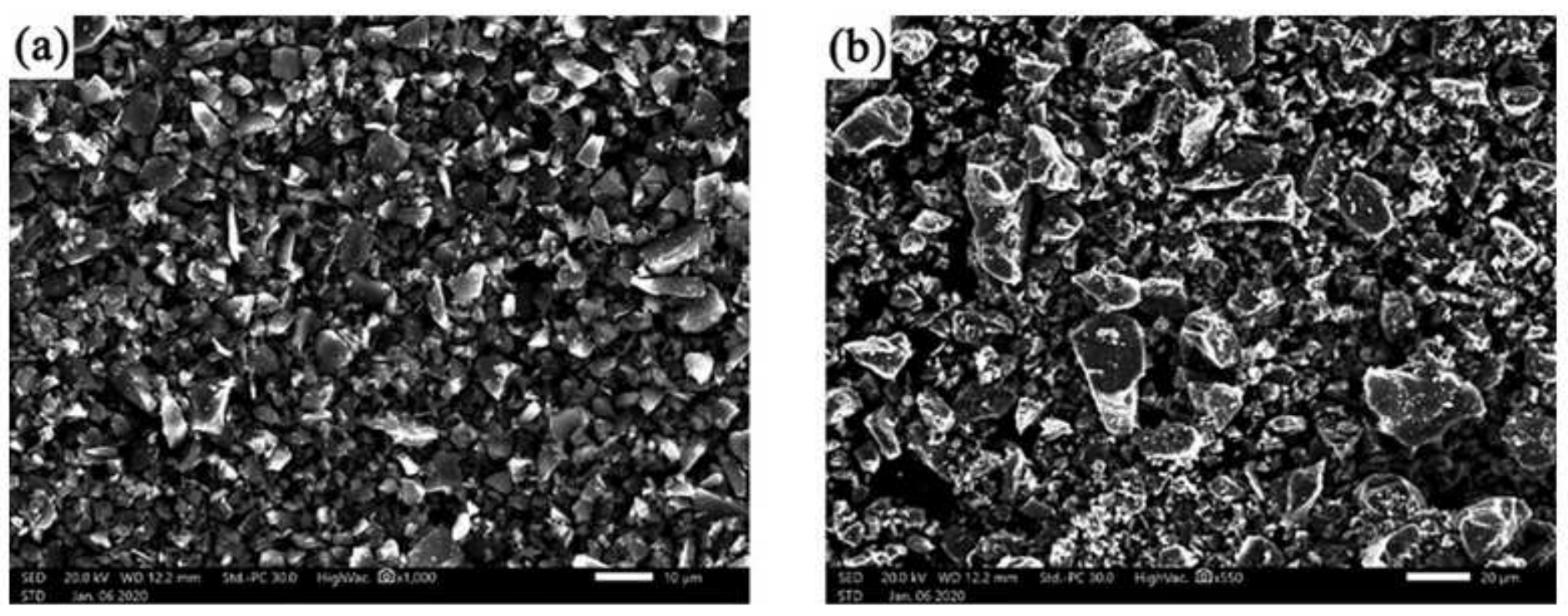

Figure 1

Microstructure of (a) B4C and (b) $\mathrm{TiH} 2$ powders.

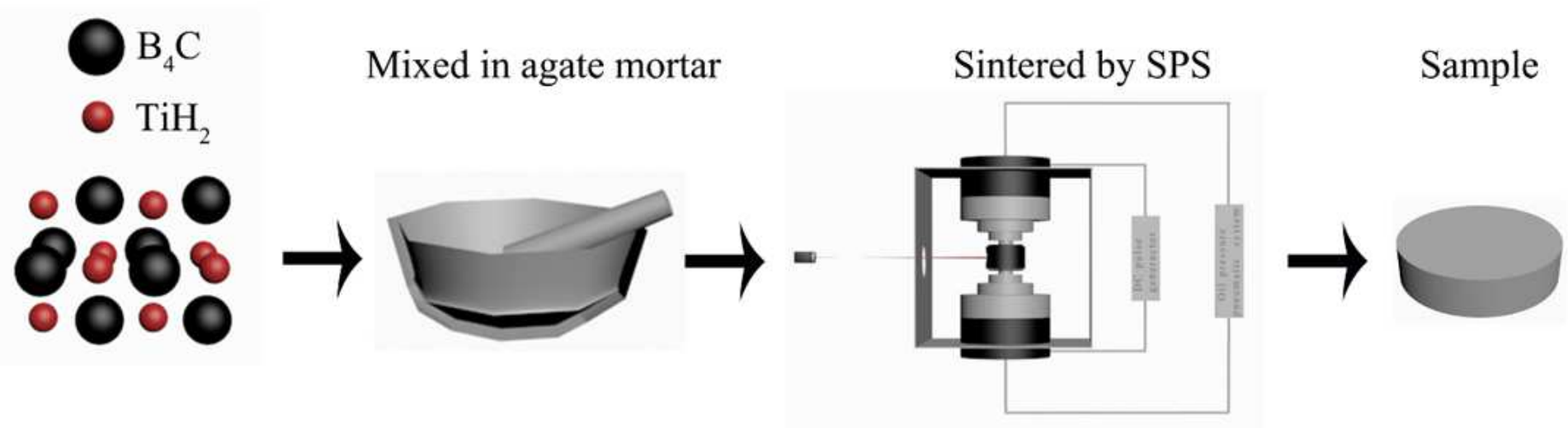

Figure 2

The procedure of sample sintering. 


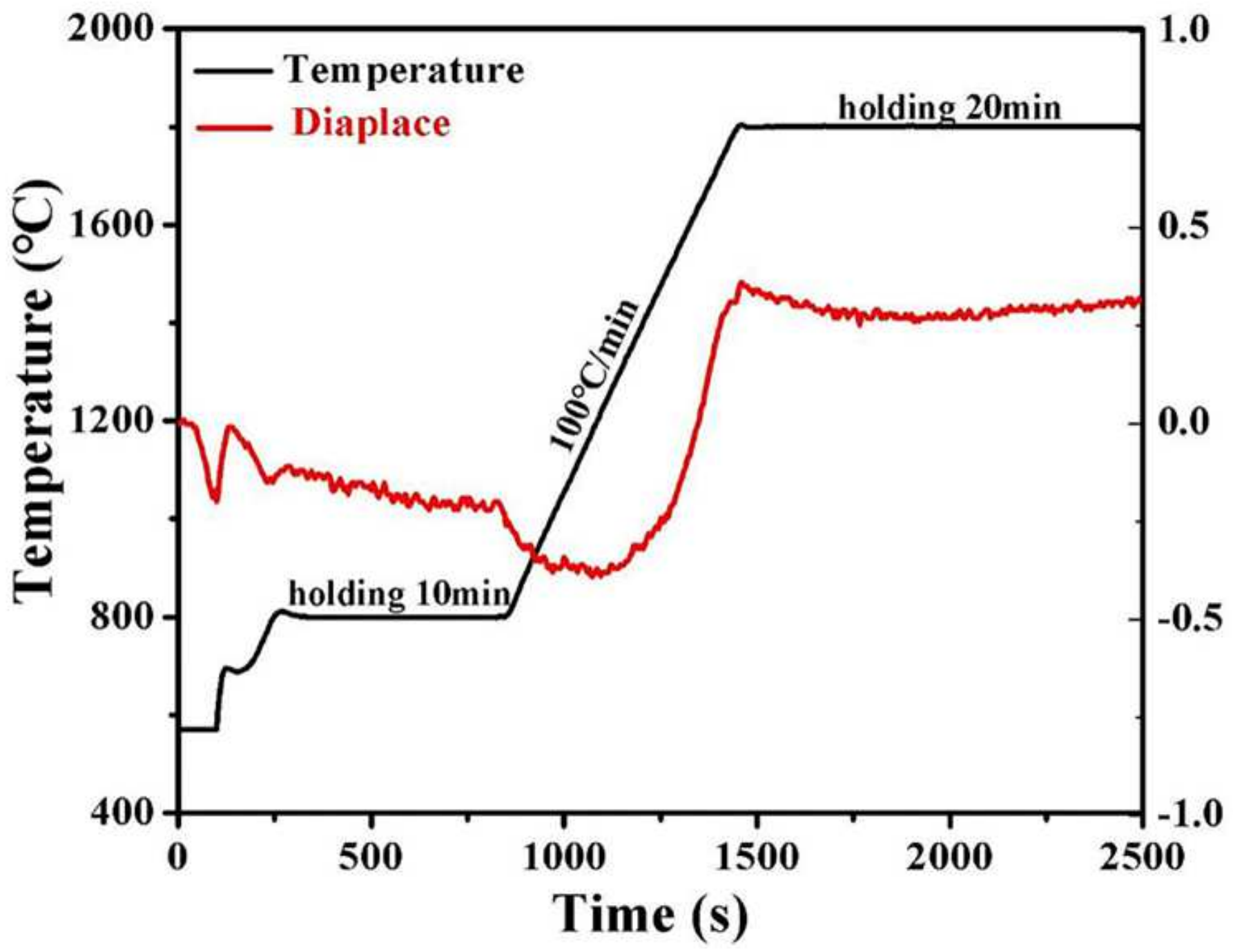

Figure 3

The temperature and displacement change at $1800 \rrbracket$ with SPS. 


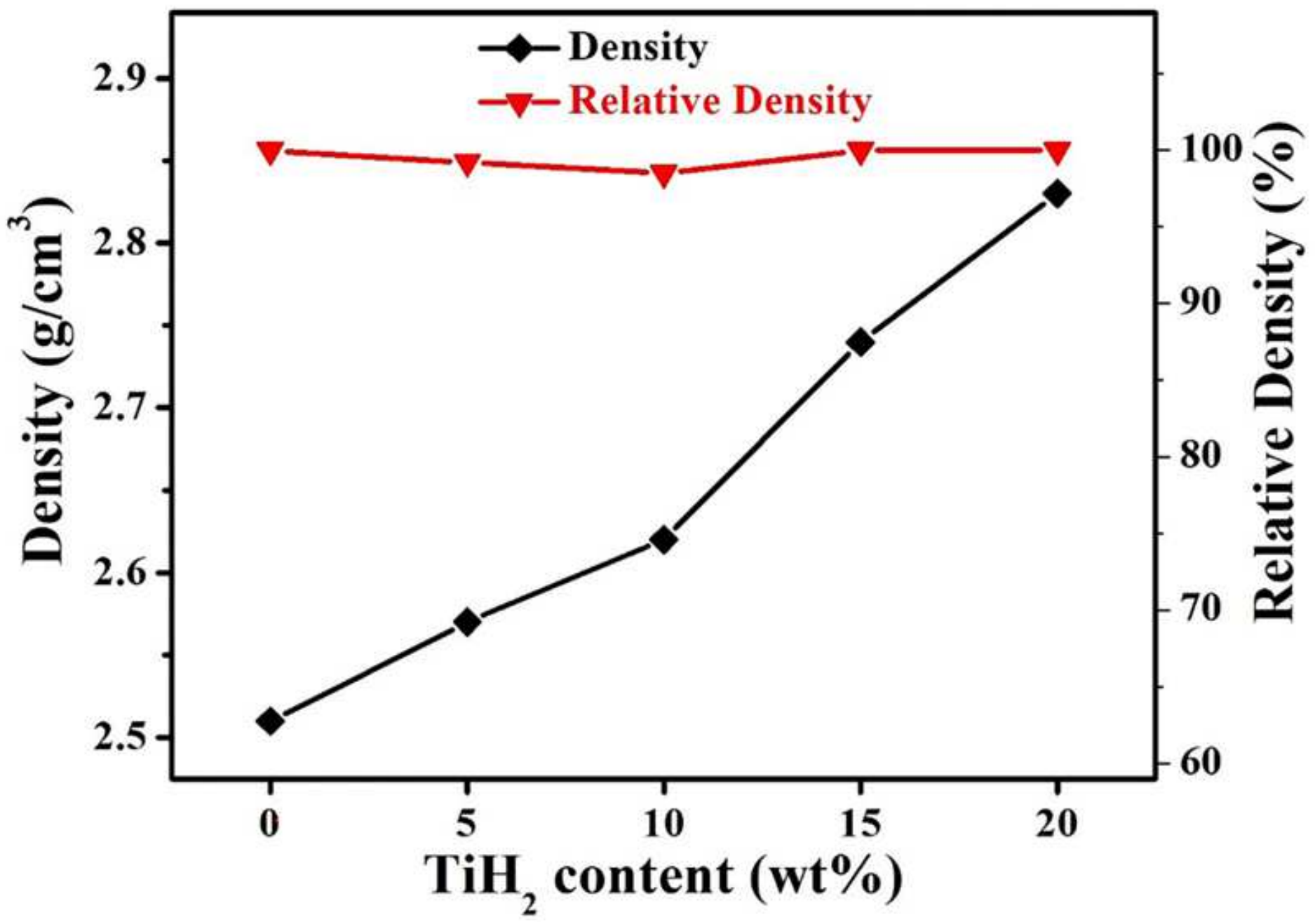

Figure 4

Density of B4C specimens as a function of (0-20) wt\% TiH2 content at 1800 \&. 


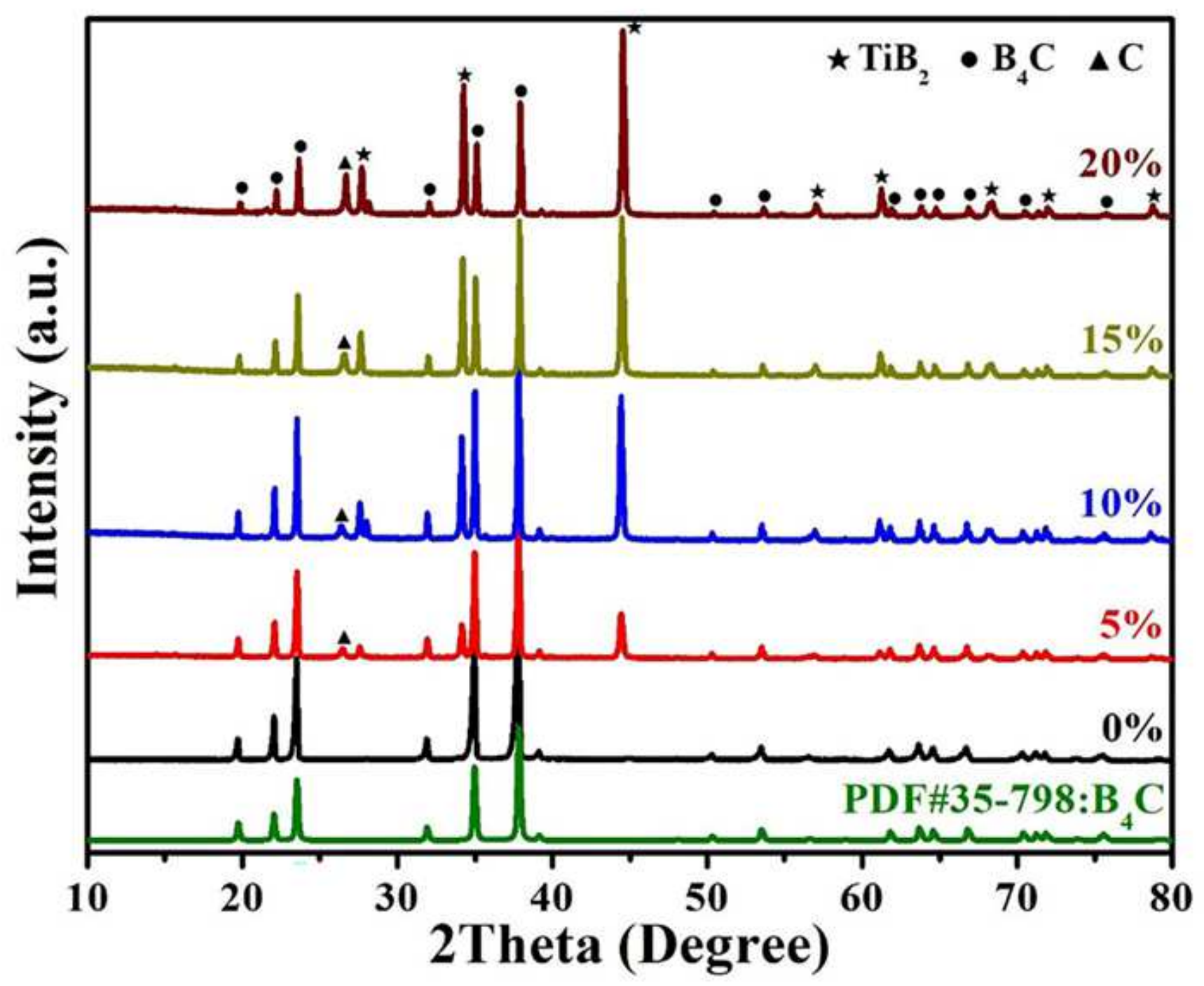

Figure 5

XRD patterns of the synthesized $B 4 C+x w t \% ~ T i H 2 ~(x=0,5,10,15,20)$ composite ceramics. 

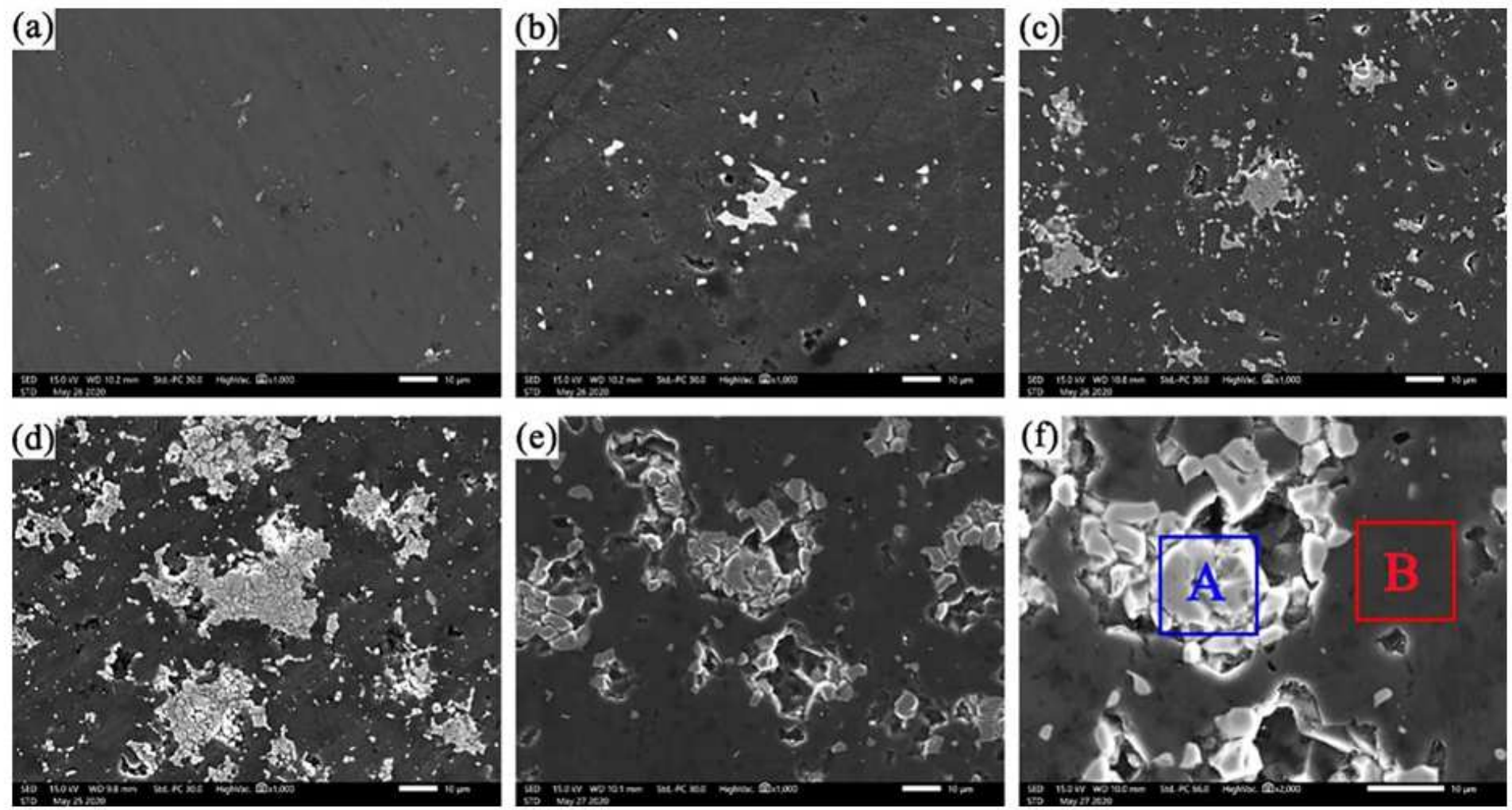

Figure 6

Polished surfaces of B4C ceramics sintered with different amount of $\mathrm{TiH} 2$ content sintered at 1800 . (a) B4C-0 wt\% TiH2; (b) B4C-5 wt\% TiH2; (c) B4C-10 wt\% TiH2; (d) B4C-15 wt\% TiH2; (e) B4C-20 wt\% TiH2; (f) The enlarged view of $\mathrm{B} 4 \mathrm{C}-20 \mathrm{wt} \% \mathrm{TiH} 2$. 
(a)

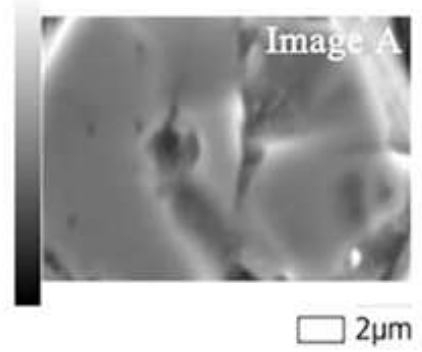

(e)

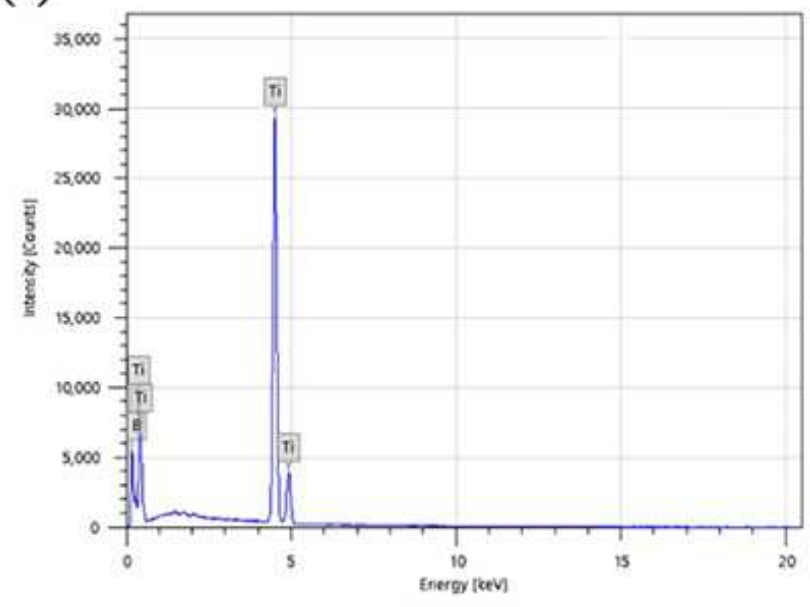

(c)

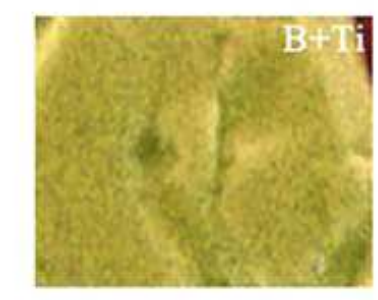

$2 \mu \mathrm{m}$

(b)

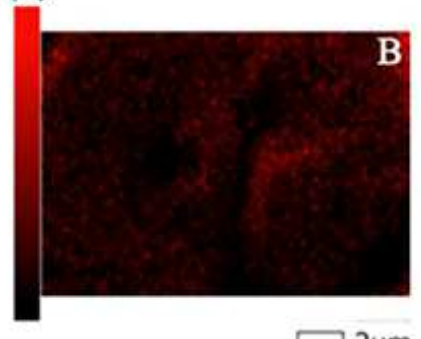

$2 \mu \mathrm{m}$ (d)

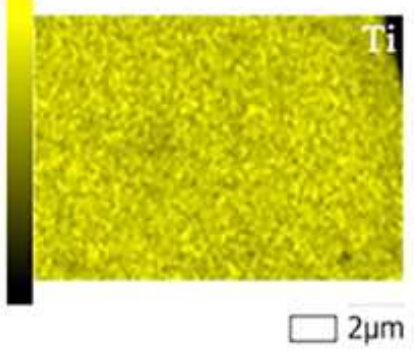

(f)

\begin{tabular}{|c|c|c|c|}
\hline Element & Line & Mass $\%$ & Atom $\%$ \\
\hline B & K & $36.00 \pm 0.04$ & $71.36 \pm 0.09$ \\
\hline Ti & K & $64.00 \pm 0.14$ & $28.64 \pm 0.06$ \\
\hline Total & & 100.00 & 100.00 \\
\hline
\end{tabular}

\section{Figure 7}

The related EDS spectra of $A$ sintered with $20 \mathrm{wt} \%$ of $\mathrm{TiH} 2$ content sintered at 1800 . (a) EDS test area image A; (b) Ti-K,B-K; (c)B-K; (d)Ti-K; (e) EDS spectra of image A; (f) Element content of image A. 
(a)

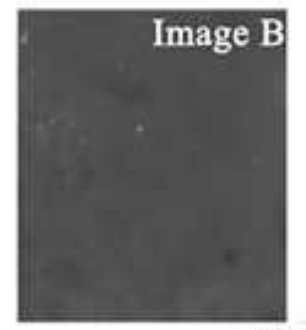

(b)

$\square 2 \mu m$

(e)

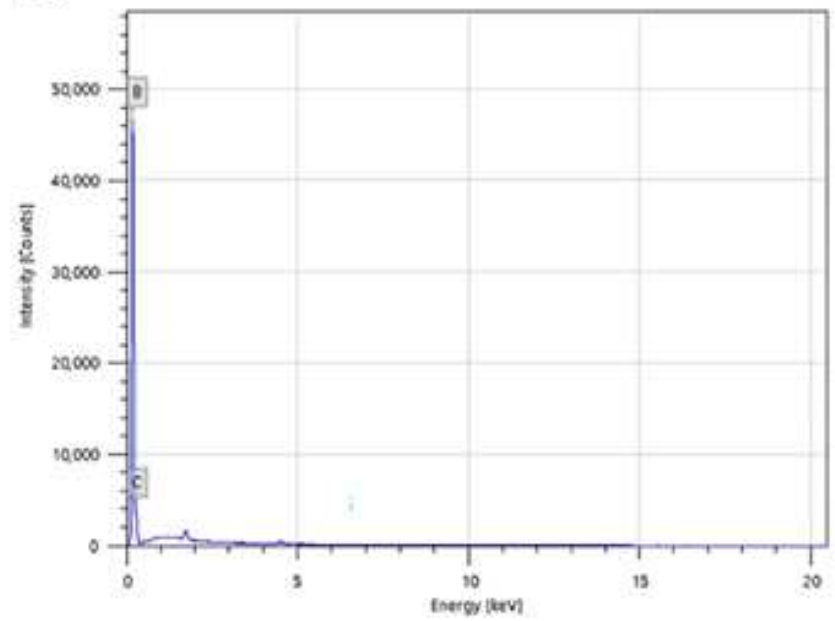

$\mathrm{B}+\mathrm{C}$ (c)
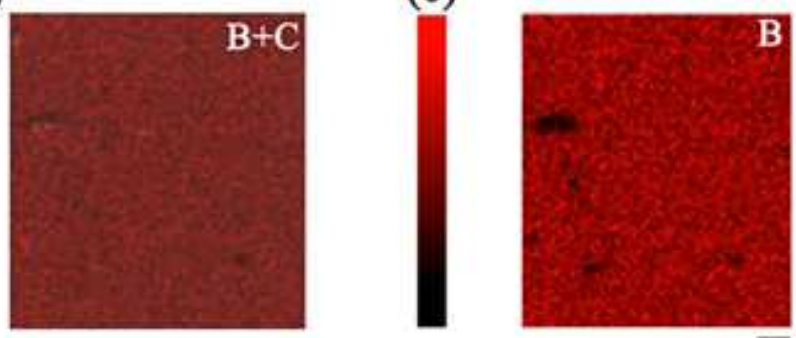

$\square 2 \mu \mathrm{m}$

(f)

\begin{tabular}{|c|c|c|c|}
\hline Element & Line & Mass $\%$ & Atom $\%$ \\
\hline B & K & $73.75 \pm 0.03$ & $75.74 \pm 0.03$ \\
\hline C & K & $26.25 \pm 0.09$ & $24.26 \pm 0.08$ \\
\hline Total & & 100.00 & 100.00 \\
\hline
\end{tabular}

Figure 8

The related EDS spectra of $\mathrm{B}$ sintered with $20 \mathrm{wt} \%$ of $\mathrm{TiH} 2$ content sintered at 1800 . (a) EDS test area image B; (b) B-K,C-K; (c)B-K; (d) C-K; (e) EDS spectra of image B; (f) Element content of image B.

(a)

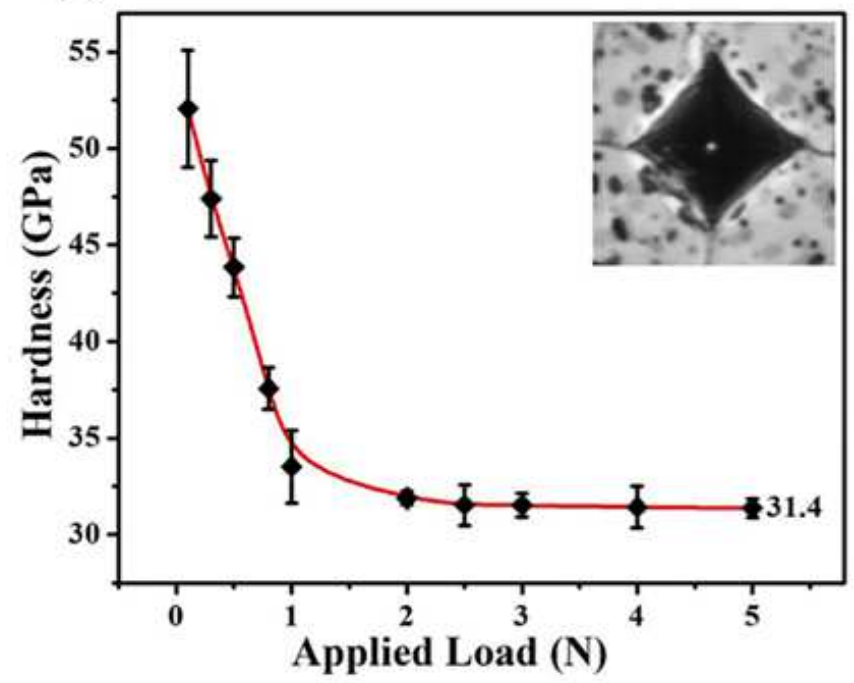

(b)

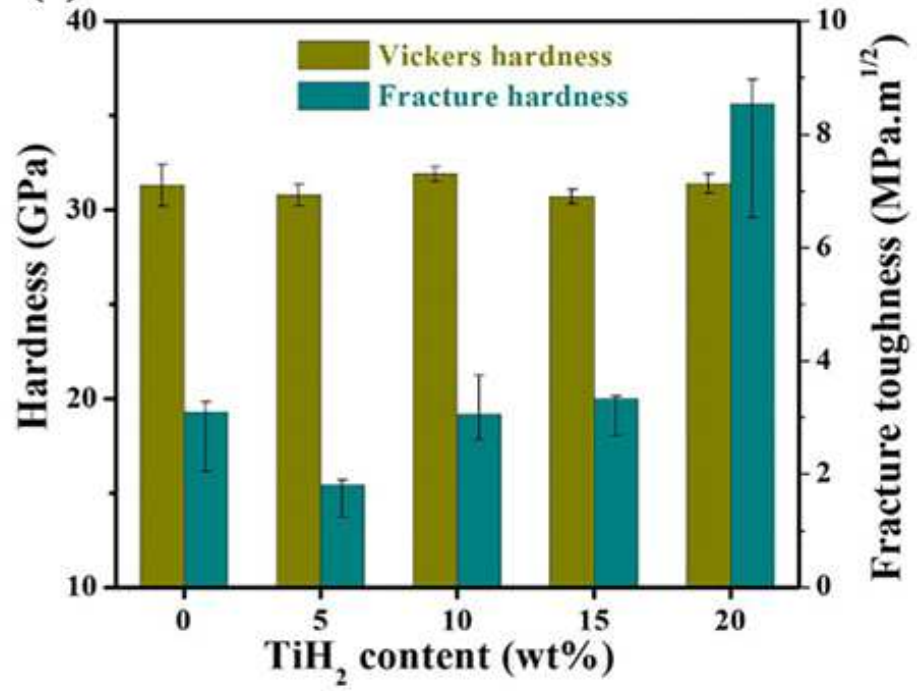

Figure 9 
Comparison of mechanical properties. (a) The measured Vickers hardness of B4C-20 wt\% TiH2 under $5 \mathrm{~N}$ load at 1800 \. (b) Effect of TiH2 addiction on the hardness and fracture toughness of B4C at 1800 .
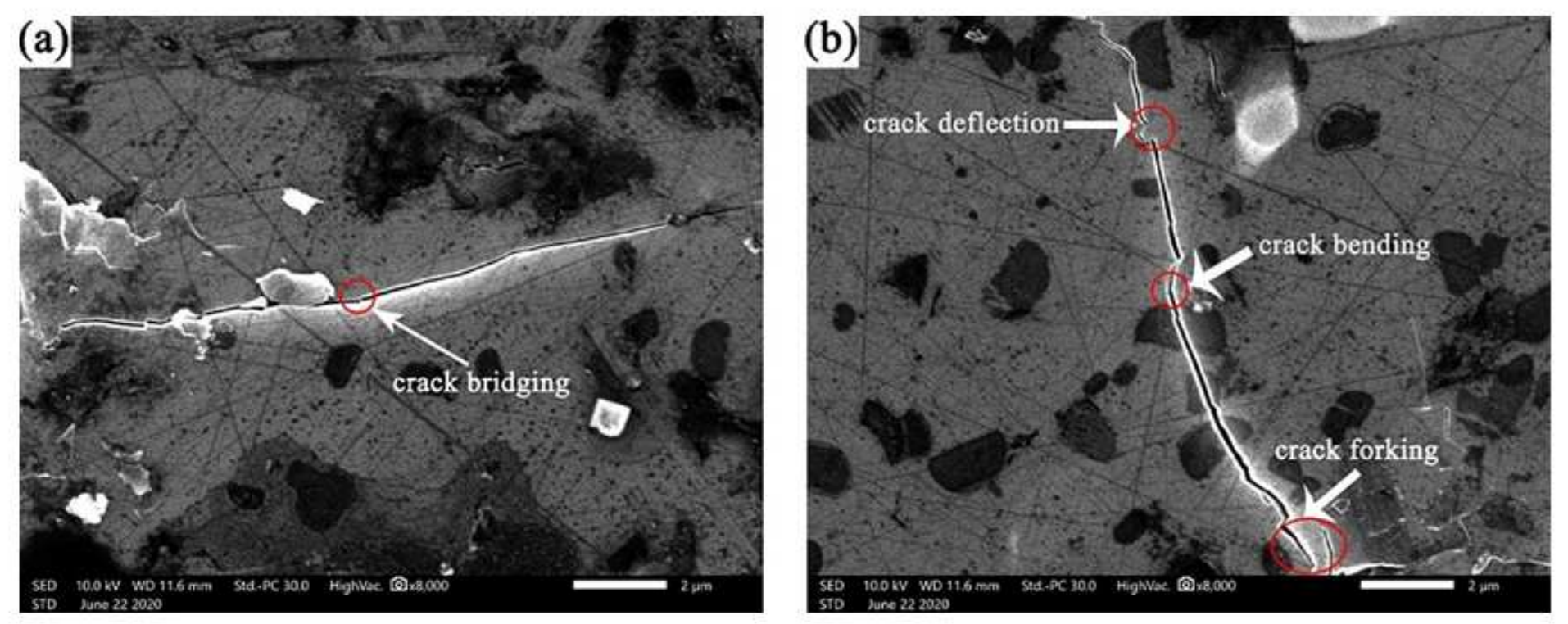

\section{Figure 10}

SEM micrographs of the polished surfaces cracks of the B4C-TiB2 composite ceramics with $20 \mathrm{wt} \% \mathrm{TiH} 2$. 


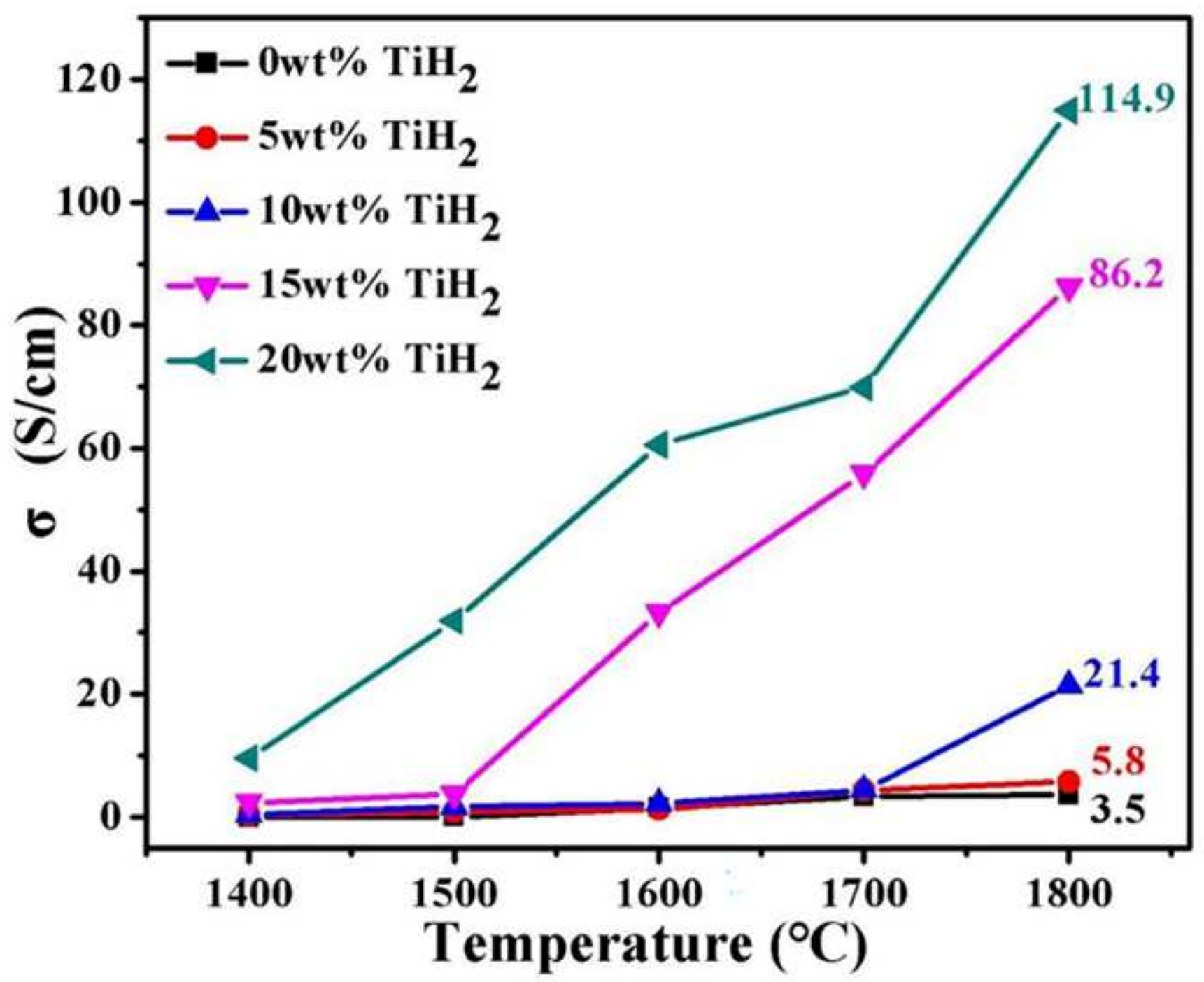

Figure 11

The electrical conductivity of B4C- $(0,5,10,15,20) \mathrm{wt} \% \mathrm{TiH} 2$ composite ceramics at different sintering temperature. 